Portland State University

PDXScholar

TREC Final Reports

Transportation Research and Education Center

(TREC)

$5-2016$

\title{
Multimodal Transportation Planning Curriculum for Urban Planning Programs
}

Kristine M. Williams

University of South Florida

Tia Claridge

University of South Florida

Alexandria Carroll

University of South Florida

Follow this and additional works at: https://pdxscholar.library.pdx.edu/trec_reports

Part of the Scholarship of Teaching and Learning Commons, Transportation Commons, and the Transportation Engineering Commons

Let us know how access to this document benefits you.

\section{Recommended Citation}

Williams, Kristine M., Claridge, Tia, and Carroll, Alexandria. Multimodal Transportation Planning Curriculum for Urban Planning Programs. NITC-ED-851. Portland, OR: Transportation Research and Education Center (TREC), 2016. https://doi.org/10.15760/trec.128

This Report is brought to you for free and open access. It has been accepted for inclusion in TREC Final Reports by an authorized administrator of PDXScholar. Please contact us if we can make this document more accessible: pdxscholar@pdx.edu. 


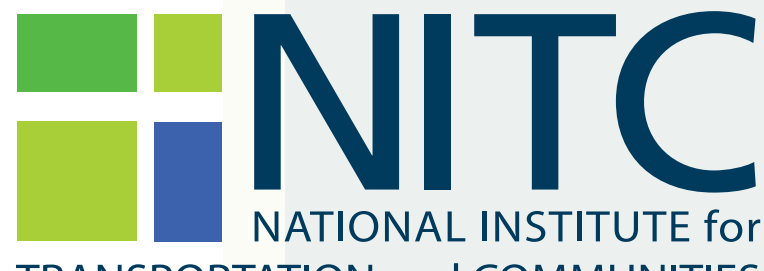

TRANSPORTATION and COMMUNITIES

FINAL REPORT

\section{Multimodal Transportation Planning Curriculum for Urban Planning Programs}

NITC-ED-851—May 2016

NITC is the U.S. Department of Transportation's national university transportation center for livable communities.

\#": TREC 


\title{
MULTIMODAL TRANSPORTATION PLANNING CURRICULUM FOR URBAN PLANNING PROGRAMS
}

\author{
Final Report \\ NITC-ED-851
}

\author{
by \\ Kristine M. Williams, AICP \\ Tia Claridge \\ Alexandria Carroll \\ University of South Florida \\ Center for Urban Transportation Research
}

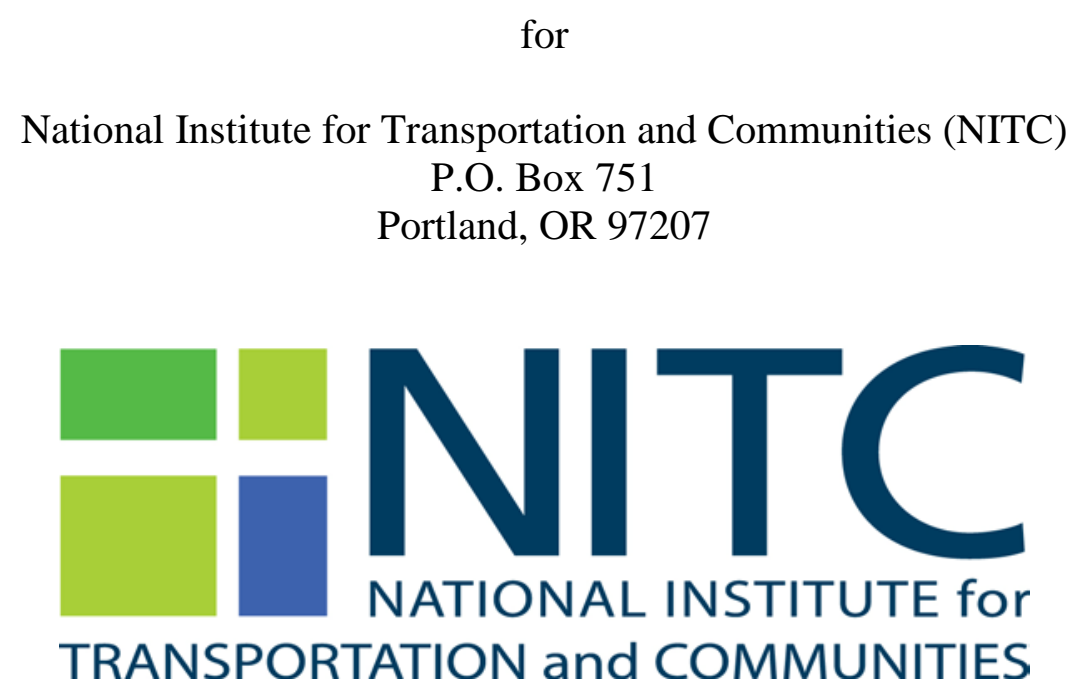

May 2016 



\begin{tabular}{|c|c|c|c|c|}
\hline \multicolumn{5}{|c|}{ Technical Report Documentation Page } \\
\hline \multirow{2}{*}{\multicolumn{3}{|c|}{ 4. Title and Subtitle }} & \multicolumn{2}{|c|}{$\begin{array}{l}\text { 5. Report Date } \\
\text { May } 2016\end{array}$} \\
\hline & & & \multicolumn{2}{|c|}{ 6. Performing Organization Code } \\
\hline \multicolumn{3}{|c|}{$\begin{array}{l}\text { 7. Author(s) } \\
\text { Kristine M. Williams, AICP, Tia Claridge, and Alexandria Carroll }\end{array}$} & \multicolumn{2}{|c|}{ 8. Performing Organization Report No. } \\
\hline \multirow{2}{*}{\multicolumn{4}{|c|}{$\begin{array}{l}\text { 9. Performing Organization Name and Address } \\
\text { Kristine M. Williams, AICP } \\
\text { CUTR, USF College of Engineering } \\
\text { 4202 E. Fowler Ave, CUT100 } \\
\text { Tampa, FL 33620-5375 }\end{array}$}} & 10. Work Unit No. (TRAIS) \\
\hline & & & \multicolumn{2}{|c|}{$\begin{array}{l}\text { 11. Contract or Grant No. } \\
01-752\end{array}$} \\
\hline \multirow{2}{*}{\multicolumn{3}{|c|}{$\begin{array}{l}\text { 12. Sponsoring Agency Name and Address } \\
\text { National Institute for Transportation and Communities (NITC) } \\
\text { P.O. Box } 751 \\
\text { Portland, Oregon } 97207\end{array}$}} & \multicolumn{2}{|c|}{$\begin{array}{l}\text { 13. Type of Report and Period Covered } \\
\text { Final Report, 06/01/2014-12.31.2015 }\end{array}$} \\
\hline & & & \multicolumn{2}{|c|}{ 14. Sponsoring Agency Code } \\
\hline \multicolumn{5}{|c|}{ 15. Supplementary Notes } \\
\hline \multicolumn{5}{|l|}{ 16. Abstract } \\
\hline \multicolumn{5}{|c|}{$\begin{array}{l}\text { Integrated multimodal transportation and land use planning is critical to advancing mode choice, public health and } \\
\text { safety, and livability objectives. Communities across the U.S. are seeking to redefine their planning process } \\
\text { accordingly. In response, university graduate urban planning and engineering programs are beginning to address } \\
\text { multimodal planning and sustainable transportation, but most do not yet offer a robust curriculum on these topics. } \\
\text { To help address this need, the University of South Florida (USF), Center for Urban Transportation Research } \\
\text { (CUTR) developed a curriculum for a course on multimodal transportation planning and its role in advancing } \\
\text { livability and related objectives. The course curriculum developed under this project was designed for integration } \\
\text { into university urban planning programs, but is also relevant to graduate-level engineering and } \\
\text { architecture/community design programs. The project is conceived in two phases, with phase one involving } \\
\text { curriculum development for the introductory course and phase two aimed at developing a course that provides } \\
\text { specific applications in multimodal planning that are reinforced through applied learning activities. This report } \\
\text { contains the phase one curriculum for the introductory course. }\end{array}$} \\
\hline \multicolumn{2}{|c|}{$\begin{array}{l}\text { 17. Key Words } \\
\text { education, multimodal transportation planning, livability, } \\
\text { curriculum }\end{array}$} & \multicolumn{3}{|c|}{$\begin{array}{l}\text { 18. Distribution Statement } \\
\text { No restrictions. Copies available from NITC: } \\
\text { www.nitc.us }\end{array}$} \\
\hline $\begin{array}{l}\text { 19. Security Classification (of this report) } \\
\text { Unclassified }\end{array}$ & $\begin{array}{l}\text { 20. Security Classificati } \\
\text { Unclassified }\end{array}$ & & 21. No. of Pages & 22. Price \\
\hline
\end{tabular}




\section{ACKNOWLEDGEMENTS}

This project was funded by the National Institute for Transportation and Communities (NITC). The report was authored by Kristine M. Williams, AICP, Principal Investigator, along with Tia Claridge and Alexandria Carroll, who provided extensive assistance in lesson plan and course material development. In addition, the authors acknowledge and thank the project advisory committee for their helpful guidance on the curriculum and available resources.

\section{Project Advisory Committee}

Dr. Mark Hafen, Assistant Director and Senior Instructor, University of South Florida School of Public Affairs, Tampa, FL

Dr. Alissa Barber Torres, Chief Planner, Orange County Transportation Planning, Orlando, FL

Lois Bush, Policy Planning Section Leader, Florida Department of Transportation District 4, Fort Lauderdale, FL

Whit Blanton, Executive Director, Pinellas Planning Council and Pinellas MPO, Clearwater, FL

\section{DISCLAIMER}

The contents of this report reflect the views of the authors, who are solely responsible for the facts and the accuracy of the material and information presented herein. This document is disseminated under the sponsorship of the U.S. Department of Transportation University Transportation Centers Program and Portland State University in the interest of information exchange. The U.S. Government and Portland State University assume no liability for the contents or use thereof. The contents do not necessarily reflect the official views of the U.S. Government and Portland State University. This report does not constitute a standard, specification, or regulation. 


\section{TABLE OF CONTENTS}

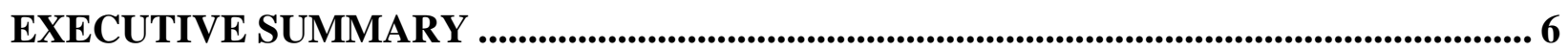

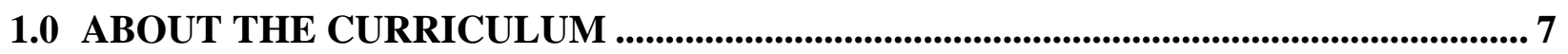

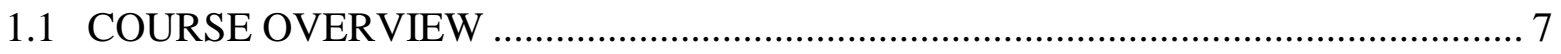

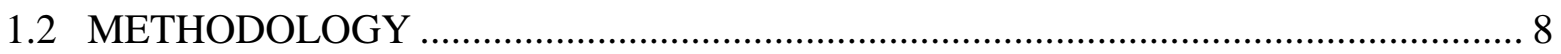

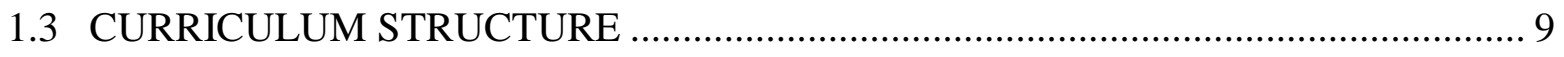

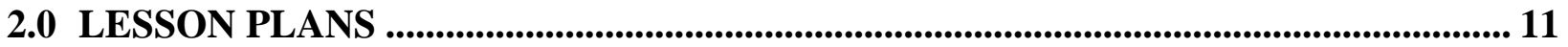
MODULE 1: HISTORICAL AND EMERGING CONTEXT FOR TRANSPORTATION PLANNING AND POLICY .............................................................................. 12 MODULE 2: CONTEMPORARY ISSUES IN TRANSPORTATION .............................. 14 MODULE 3: THE GOVERNANCE AND EQUITY OF TRANSPORTATION ............... 18 MODULE 4: MULTIMODAL PLANNING CONCEPTS AND PROCESS ...................... 20 MODULE 5: TRANSPORTATION, LAND USE AND URBAN FORM........................ 22 MODULE 6: TRANSPORTATION AND LAND USE PLANNING BEST PRACTICES 24 MODULE 7: TRAVEL PATTERNS AND BEHAVIOR .............................26 MODULE 8: NON-MOTORIZED TRANSPORTATION: WALKING AND BICYCLING

MODULE 9: TRANSIT AND LAND USE ................................................................. 30

MODULE 10: FREIGHT AND GOODS MOVEMENT .................................................. 32

MODULE 11: TRANSPORTATION DEMAND AND SYSTEMS MANAGEMENT ...... 34

MODULE 12: FUNDING MULTIMODAL TRANSPORTATION SYSTEMS ................. 36

MODULE 13: EVALUATING SYSTEM PERFORMANCE ......................................... 38

MODULE 14: COURSE WRAP-UP .................................................................. 40

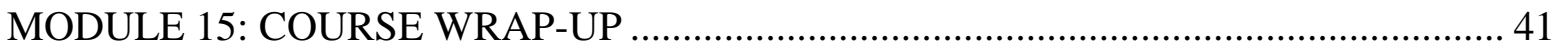

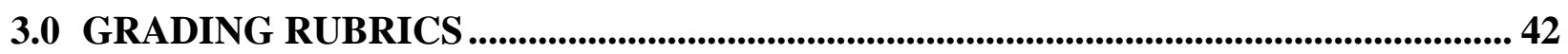

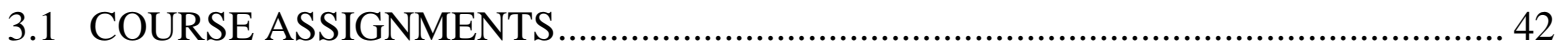

3.2 FINAL PAPER ................................................................................................. 43

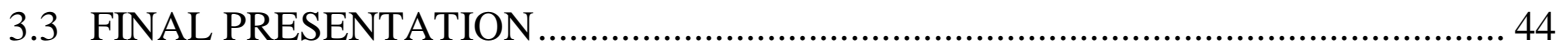

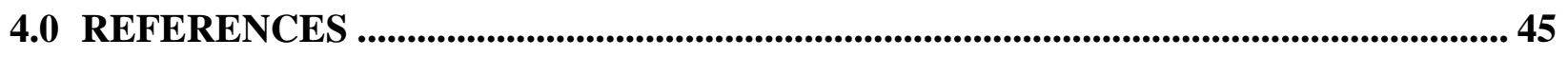

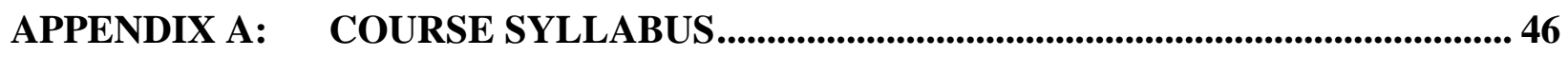

APPENDIX B: SAGA CITY EXERCISE ...................................................................6 66

APPENDIX C: PUBLIC MEETING ROLE PLAY HANDOUT ................................. 68

APPENDIX D: EVALUATING SYSTEM PERFORMANCE HANDOUT ..................... 81 


\section{EXECUTIVE SUMMARY}

Integrated multimodal transportation and land use planning is essential to advancing mode choice, public health and safety, equity, and livability objectives. Communities across the U.S. are seeking to redefine their planning process to include multimodal transportation considerations. In response, university graduate urban planning and engineering programs are beginning to address multimodal planning and sustainable transportation in their curricula, but most do not yet offer a robust course on these topics. To help address this need, the University of South Florida (USF), Center for Urban Transportation Research (CUTR) has developed a model curriculum for graduate-level multimodal transportation planning courses. The curriculum is designed for integration into university urban planning programs, but is also relevant to graduatelevel engineering, sustainability, public administration, and architecture and community design programs. The project was conceived in two phases, with this introductory course comprising phase one and applied methods in multimodal transportation planning comprising phase two.

This curriculum provides students an introductory understanding of multimodal transportation planning principles and practices. Each course module is devoted to a key topic or theme in multimodal transportation planning. These are listed below:

- Historical Context and Emerging Issues for Transportation Planning and Policy

- Contemporary Issues in Transportation

- The Governance and Equity of Transportation

- Multimodal Planning Concepts and Process

- Transportation, Land Use, and Urban Form

- Transportation and Land Use Planning Best Practices

- Travel Patterns and Behavior

- Non-Motorized Transportation: Walking and Bicycling

- Transit and Land Use

- Freight and Goods Movement

- Transportation Demand and Systems Management

- Funding Multimodal Transportation Systems

- Evaluating System Performance

The final report contains a variety of materials to assist instructors in teaching the course:

- Lesson plans for each module, including course objectives, required and optional readings, lecture content, and class activities;

- PowerPoint presentations for each module, including lecture notes for the instructor (provided separately);

- A syllabus containing the course objectives, assignments, grading structure, and schedule;

- Grading rubrics for each assignment; and

- Handouts to support lecture content and in-class activities. 


\subsection{ABOUT THE CURRICULUM}

The Multimodal Transportation Planning Curriculum for Urban Planning Programs is a joint project between the University of South Florida (USF), Center for Urban Transportation Research (CUTR) and the National Institute for Transportation and Communities (NITC). The objective of this project is to address the educational needs of graduate students in urban and regional planning and engineering programs as they relate to multimodal planning and sustainable transportation. This curriculum specifically addresses multimodal transportation planning and its role in advancing livability and related objectives. This report summarizes the information included in the course, supplemental materials developed from the course, course assessment and relevant information to guide the instructor, as well as any future efforts to expand upon the curriculum. The following sections may be used by each instructor to develop the course syllabus.

\subsection{COURSE OVERVIEW}

Integrated multimodal transportation and land use planning is critical to advancing mode choice, public health and safety, and livability objectives. Communities across the U.S. are seeking to redefine their planning process accordingly. In response, university graduate urban planning and engineering programs are beginning to address multimodal planning and sustainable transportation, but most do not yet offer a robust curriculum on these topics. To help address this need, the University of South Florida (USF), Center for Urban Transportation Research (CUTR) was awarded a grant from the National Institute of Transportation and Communities (NITC) to develop a curriculum for a course on multimodal transportation planning and its role in advancing livability and related objectives.

The course curriculum developed under this project was designed for integration into university urban planning programs, but is also relevant to graduate-level engineering and architecture/community design programs. The project is conceived in two phases, with phase one involving curriculum development for the introductory course and phase two aimed at developing a course that provides specific applications in multimodal planning that are reinforced through service learning activities. These two phases are proposed as year-one and year-two activities. This report contains the phase-one curriculum for the introductory course. This course will be further developed as an introductory course preparing students to take a second multimodal transportation course which provides specific applications in multimodal planning that are reinforced through applied learning activities. 


\subsubsection{Background}

The course curriculum builds upon a course entitled Multimodal Transportation Planning (URP6930/PAD6934) that was offered at the University of South Florida in the spring of 2015 as an elective to students in the Urban and Regional Planning Program and Public Administration Program at USF. Previously, only the College of Engineering offered courses related to transportation; students taking these courses were instructed primarily on the technical characteristics of transportation. This course in multimodal transportation was designed to close the gap between the technical elements of transportation planning and the best practices and policies designed to ensure the effectiveness of transportation systems relative to all modes.

The course is adapted in part from research and training materials for practicing planners that was produced for the National Center for Transit Research (NCTR) and the Florida Department of Transportation (FDOT). Course materials draw from the following reports:

- Multimodal Transportation Best Practices and Model Element (NCTR, 2014), and

- Mobility Review Guide and Checklist (2014).

Supplemental documents include various journal articles, guidebooks, comprehensive plans and reports. Links to all reading materials for the course are included in the lesson plans as well as the attached syllabus.

\subsubsection{Course Objectives}

The course is designed to familiarize students with the following:

- The historical evolution of transportation planning, policy and practice in the U.S.;

- The social, economic and environmental implications of various modes of transportation, including the relationship between transportation, urban form and public health;

- The institutional, political, legal and financial considerations in transportation planning;

- Multimodal planning best practices in transportation and land use planning; and

- Evaluation of the relative strengths and weaknesses of local transportation plans from a multimodal and multijurisdictional perspective.

\subsection{METHODOLOGY}

Development of the curriculum began with an evaluation of available materials, including courses and syllabi from various universities that relate to multimodal transportation. These materials include University of Central Florida's “Sustainable Transportation Planning," developed and taught by Dr. Alissa Barber Torres; the American Institute of Certified Planners course "Sustainable Transportation" offered by Dr. Reid Ewing of the University of Utah and Jeffrey Tumlin of Nelson Nygaard; relevant model curricula, including those developed by NITC on bicycle and pedestrian planning and design; and literature on curriculum development primarily from USF Academy for Teaching and Learning Excellence "Preparing for College Teaching.” The curriculum also builds upon information in the FDOT research reports 
"Multimodal Transportation Planning Best Practices and Model Element" and the "Mobility Review Guide.”

A Project Advisory Committee (PAC) was formed to aide in the development of the curriculum and provide necessary feedback throughout the curriculum development process. PAC members include individuals representing academia, local government and the private sector with expertise in fields related to multimodal transportation and planning. These individuals contributed to every aspect of the curriculum development, and provided necessary resources and information to ensure the production of a high-quality multimodal transportation curriculum.

\subsection{CURRICULUM STRUCTURE}

This curriculum introduces multimodal planning best practices in preparation for the second multimodal transportation course, which includes multimodal transportation applications and applied learning projects. The curriculum content is divided into 15 modules, 13 of which are inclass lessons taught by the instructor using PowerPoint and other materials. The final two modules are reserved for students to present their final projects.

This document contains materials necessary for the successful instruction of this multimodal transportation course. Section 1 introduces the reader to the multimodal curriculum. Section 2 includes lesson plans for each module which outline the lesson objectives, assignments, readings, lecture content, assessment tools, activities and necessary instructional resources. Additionally, instructor's notes are included at the end of each lesson plan, providing the instructor with pertinent information about the module that may not be explicitly stated in the lesson plan. The majority of readings listed in both the lesson plan and syllabus can be found online at no cost to the instructor or students, although there are several texts and documents which can be requested through the college/university library. Section 3 includes all grading rubrics for course assignments, the final project and the final presentation.

Appendices are located at the end of this document. Appendices include the course syllabus, Saga City exercise used in Module 2, public meeting role play handout used in Module 3 , and evaluating system performance handout used in Module 13. Additional materials including PowerPoint presentations, in-class videos, and other handouts can be found in the curriculum folder that accompanies this final report. PowerPoint presentations, which are the primary tool for in-class lectures, include speaker notes that provide additional information for the instructor on the slide and lecture content. 



\subsection{LESSON PLANS}

The course was divided into a series of lesson plans to guide the instructor in teaching the class. There are a total of 15 lesson plans, or modules, with each representing a week of instruction. Each lesson plan includes the following elements:

- $\quad$ Topic. This is the overall theme or topic for each module.

- Objectives. The objectives briefly describe the purpose of the lesson and identify expected student learning outcomes.

- Assignments Due. This section identifies any assignments that are due that week. Full assignment descriptions can be found in Appendix A: Course Syllabus. Grading rubrics for each assignment can be found in Section 3.0.

- Readings. This section lists both required and optional readings for each module. It includes full citations and links to online readings for quick and easy access to materials.

- Lecture Content. This section summarizes the key subtopics to be discussed for each module.

- Assessments and Activities. This section briefly describes any assessments or in-class activities to be conducted for the given module. Accompanying notes and materials to guide the instructor can be found in the Instructor's Notes following each lesson plan.

- Instructional Resources. This section outlines the materials needed to conduct each lesson. Resources may include PowerPoints, outlines, handouts, videos, et cetera.

- Instructor's Notes. Instructor's notes may be included at the end of the lesson plan to provide additional information for the instructor. These may include directions for inclass activities, notes regarding assigned readings, or other need-to-know information not contained within the previous sections. 


\section{MODULE 1: HISTORICAL AND EMERGING CONTEXT FOR TRANSPORTATION PLANNING AND POLICY}

\begin{tabular}{|c|c|}
\hline \multicolumn{2}{|l|}{ Module 1} \\
\hline Topic & $\begin{array}{l}\text { Historical and Emerging Context for Transportation Planning } \\
\text { and Policy }\end{array}$ \\
\hline Objectives & $\begin{array}{l}\text { This lesson will review the historical and emerging context for } \\
\text { transportation planning and policy in the U.S., with an emphasis on } \\
\text { key legislation and policy and modal issues impacting the evolving } \\
\text { practice of transportation planning. } \\
\text { At the end of this lesson students will be able to: } \\
\text { - Identify key eras and events in transportation history, } \\
\text { including changes in federal transportation policy. } \\
\text { - Understand the impetus for the emergence of metropolitan } \\
\text { planning organizations. } \\
\text { - Understand how urban planning practice has evolved in } \\
\text { response to the automobile and impacts of these changes on } \\
\text { how we plan for mobility. }\end{array}$ \\
\hline Assignments Due & N/A \\
\hline Readings & $\begin{array}{l}\text { Required } \\
\text { - Rosenbloom, S. \& Beck, A. (2000). The practice of local } \\
\text { government planning ( } 3^{\text {rd }} \text { ed.). Washington, D.C.: } \\
\text { International City/County Management Association. } \\
\text { o Chapter 9: Transportation Planning } \\
\text { - Federal Highway Administration \& Federal Transit } \\
\text { Administration. (2012). Federal strategies for implementing } \\
\text { requirements for LRTP update for the Florida MPOs. } \\
\text { Retrieved from } \\
\text { http://www.dot.state.fl.us/planning/revenueforecast/usdot.pd } \\
\text { f. } \\
\text { Florida Department of Transportation. (2014). Multimodal } \\
\text { transportation best practices and model element. Retrieved } \\
\text { from http://www.dot.state.fl.us/research- } \\
\text { center/Completed_Proj/Summary_PL/FDOT-BDK85-977- } \\
\text { 49-rpt.pdf. } \\
\text { o Chapter 3: Model Element for Small Communities } \\
\text { - and Rural Areas } \\
\text { U.S. Department of Transportation. (2015). Planning } \\
\text { emphasis areas for federal fiscal year 2016. Retrieved from } \\
\text { https://www.fhwa.dot.gov/planning/processes/metropolitan/ } \\
\text { mpo/fy_2016/fy2016pea.pdf. } \\
\text { U.S. Department of Transportation. (2015). Beyond traffic } \\
\text { 2045: Trends and choices. Retrieved from } \\
\text { https://www.transportation.gov/sites/dot.gov/files/docs/Draft } \\
\text { _Beyond_Traffic_Framework.pdf. }\end{array}$ \\
\hline
\end{tabular}




\begin{tabular}{|c|c|}
\hline & $\begin{array}{l}\text { Optional } \\
\text { - Weiner, E. (1992). Urban transportation planning In the } \\
\text { United States: An historical overview. Westport, CT: } \\
\text { Praeger. Online access: http://ntl.bts.gov/DOCS/UTP.html. }\end{array}$ \\
\hline Lecture Content & 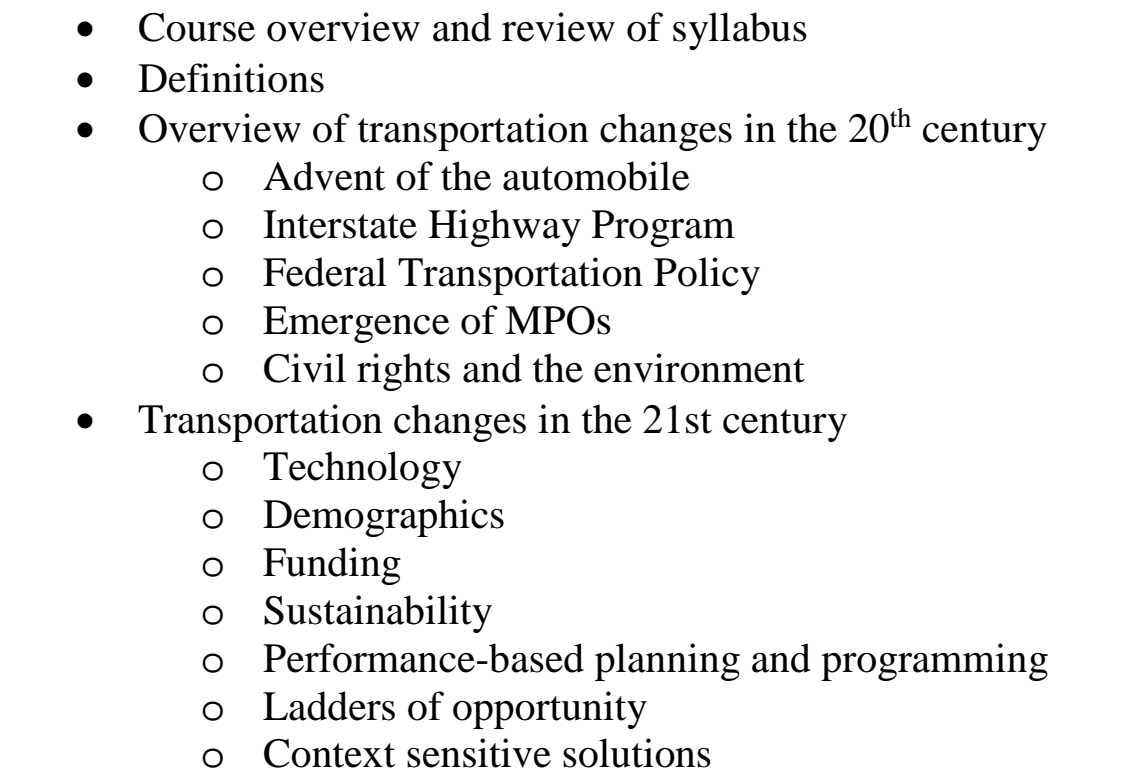 \\
\hline Assessment/Activities & $\begin{array}{ll}\text { - } & \text { Instructor and student introductions and icebreakers } \\
\text { - } & \text { Discussion of Beyond Traffic } 2045 \text { video }\end{array}$ \\
\hline $\begin{array}{l}\text { Instructional } \\
\text { Resources }\end{array}$ & $\begin{array}{l}\text { - } \text { Syllabus } \\
\text { - } \text { PowerPoint presentation } \\
\text { o Historical Context } \\
\text { - } \quad \text { Definitions and key terms handouts } \\
\text { - } \quad \text { Beyond Traffic } 2045 \text { video }\end{array}$ \\
\hline
\end{tabular}

\section{Instructor's Notes}

- Rosenbloom and Beck provide an excellent and concise overview of the history and context for transportation planning in the U.S. This book may be available through the university/college library. Otherwise, students may need to purchase it. Alternatively, upon the instructor's request, many libraries will scan hard copies of the text and make them available for courses.

- In-Class Activity: Icebreakers

- This activity is intended to "break the ice” and familiarize students with their classmates.

- Ask students to discuss transportation in the area where they lived previously, highlighting characteristics of the transportation system.

- Ask students to state their total commute time on a typical day and discuss their responses with each other, including the effects of their preferred mode of transportation on their community and the environment. 


\section{MODULE 2: CONTEMPORARY ISSUES IN TRANSPORTATION}

\begin{tabular}{|c|c|}
\hline \multicolumn{2}{|l|}{ Module 2} \\
\hline Topic & Contemporary Issues in Transportation \\
\hline Objectives & $\begin{array}{l}\text { This lesson will provide students with an understanding of contemporary } \\
\text { issues that relate to transportation outcomes and how we plan for mobility. } \\
\text { At the end of this lesson students will be able to: } \\
\text { - Identify critical issues in multimodal transportation planning. } \\
\text { - Understand how transportation and land use planning practices } \\
\text { impact public health, the natural and built environment, the } \\
\text { economy, community cohesion, and social equity. }\end{array}$ \\
\hline Assignments Due & N/A \\
\hline Readings & $\begin{array}{l}\text { Required } \\
\text { - Transportation Research Board. (2013). Critical issues in } \\
\text { transportation. Retrieved from } \\
\text { http://onlinepubs.trb.org/Onlinepubs/general/criticalissues13.pdf. } \\
\text { - Gallivan, F., Rose, E., Ewing, R., Hamidi, S., \& Brown, T. (2015). } \\
\text { TCRP report 176: Quantifying transit's impact on GHG emissions } \\
\text { and energy use: The land use component. Transportation Research } \\
\text { Board of the National Academies: Washington, D.C. Retrieved from } \\
\text { http://onlinepubs.trb.org/onlinepubs/tcrp/tcrp_rpt_176.pdf. } \\
\text { o Executive Summary, Section 2, and Section 4. } \\
\text { Ewing, R., Bartholomew, K., Winkelman, S., Walters, J., \& Chen, } \\
\text { D. (2007). Growing cooler: The evidence on urban development and } \\
\text { climate change. Washington, D.C.: Urban Land Institute. Retrieved } \\
\text { from } \\
\text { http://www.smartgrowthamerica.org/documents/growingcoolerCH1. } \\
\text { pdf. } \\
\text { o Chapter 1: Overview } \\
\text { Tumlin, J. (2012). Sustainable transportation planning: Tools for } \\
\text { creating vibrant, healthy, and resilient communities. Hoboken, NJ: } \\
\text { John Wiley \& Sons. Inc. } \\
\text { o Chapter 3: Transportation and Public Health } \\
\text { American Society of Civil Engineers. (2013). 2013 report card for } \\
\text { America's infrastructure. Retrieved from } \\
\text { http://www.infrastructurereportcard.org/. } \\
\text { o Overview, Economic Impact, National Grades }\end{array}$ \\
\hline Lecture Content & 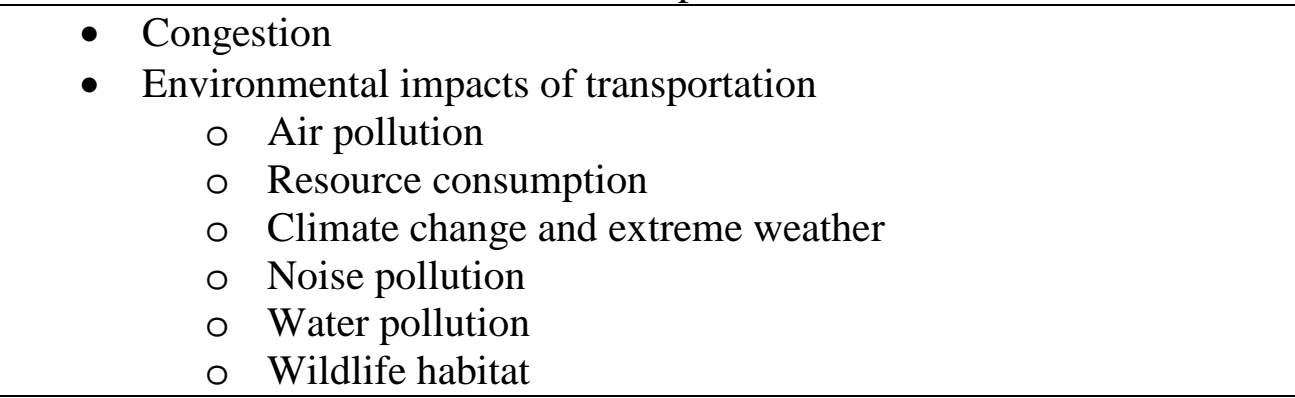 \\
\hline
\end{tabular}




\begin{tabular}{|c|c|}
\hline & $\begin{array}{l}\text { - Energy efficiency and dependence } \\
\text { - } \quad \text { Livability and economic prosperity } \\
\text { - Public health and safety } \\
\text { - } \quad \text { Suburban sprawl and auto-dependence } \\
\text { - } \text { Aging infrastructure and the economy }\end{array}$ \\
\hline Assessment/Activities & Activity: Discussion of Saga City Video (30 minutes) \\
\hline $\begin{array}{l}\text { Instructional } \\
\text { Resources }\end{array}$ & $\begin{array}{l}\text { - PowerPoint presentation } \\
\text { - Saga City video: http://vimeo.com/28464164 } \\
\text { - Saga City activity worksheet }\end{array}$ \\
\hline
\end{tabular}

\section{Instructor's Notes}

- In-Class Activity: Saga City

o This activity is intended to supplement the lecture for this module and encourage students to think critically about transportation trends and issues.

o Show Saga City video in two parts ( 30 minutes total). Use Saga City activity worksheet found in Appendix B: Saga City Exercise. Internet access required! Saga City is at http://vimeo.com/28464164.

1. View Part 1 of the video. (TO 6:56)

a. List the transportation and land use actions that contribute to the problems experienced by the City of Colvert.

i. Share the answers with your neighbors and expand on them as needed.

Be prepared to share your responses with the larger group.

ii. Discussion questions:

1. Why can't anyone get anywhere by walking anymore?

2. Did the bypass help? Why or why not? What about the limited access freeway?

3. How did zoning contribute?

4. What happened to the urban core?

2. View Part 2 of the video.

a. Work with your neighbor to list at least three strategies the City of Colvert used to achieve its vision of a better future (answers listed below). What additional strategies could the City have used to achieve their vision? Share the answers with your neighbors and expand on them as needed. Be prepared to share your responses with the larger group.

i. Who was called upon to find solutions? Businessmen, architects, urban planners, and other specialists?

ii. Why did the town establish a growth boundary?

iii. What did they do to create neighborhood centers?

iv. What was the biggest step they had to take to change? 

- Strategies the City of Colvert used to achieve its vision:

o Reduced urban boundary

- Less available land

- More compact building

- More compact neighborhoods

o Encouraged downtown development

- Got two major employers to move there

- More people, services, businesses

- Enjoyable streets, squares, public parks

o Abandoned warehouse district

- City helped create incentives

- New services, shops, housing

- Green

o Train station became bus terminal and more

- Neighborhood was made ped/bike friendly

- Increased transit use

- Lively ped street where cars do not have sole priority

o Shopping center turned into new urban neighborhood

- Multilevel parking

o Surface space became new buildings

o Tangletown

- Drainage to landscaped retention areas = loss of heat islands

- Community center

- Zoning for stores, businesses

- Pedestrian shortcuts

- Bus service

o New eco-friendly neighborhood near old mill

- Stringent construction rules

- Buildings not exposed to elements

- Density makes infrastructure more efficient

o Linked transit system

- Reliable

- Good buses, shelters

o Decreased downtown parking

- Added carshare

- Self-serve bike service

- YET TO DO

- Make bypass road friendlier for all

- Light rail to replace bus

- Connect neighboring cities by train

- Improve greenhouse gas emissions

- City is clean, prosperous, politically popular 
MODULE 3: THE GOVERNANCE AND EQUITY OF TRANSPORTATION

\begin{tabular}{|c|c|}
\hline \multicolumn{2}{|l|}{ Module 3} \\
\hline Topic & The Governance and Equity of Transportation \\
\hline Objectives & $\begin{array}{l}\text { This lesson provides students with a comprehensive look at } \\
\text { institutional structures for transportation governance in the U.S., } \\
\text { roles of the various governmental agencies, and contemporary } \\
\text { governance challenges in multimodal planning. } \\
\text { After completing this lesson, students will be able to: } \\
\text { - Identify the roles of entities involved in transportation } \\
\text { planning. } \\
\text { - Understand the laws and planning processes that guide } \\
\text { MPOs. } \\
\text { - Understand the political and institutional issues that impede } \\
\text { coordinated planning. } \\
\text { Understand how social equity is addressed through } \\
\text { multimodal transportation planning }\end{array}$ \\
\hline Assignments Due & N/A \\
\hline Readings & $\begin{array}{l}\text { Required } \\
\text { U.S. Department of Transportation. (2015). The } \\
\text { transportation planning process briefing book: Key issues for } \\
\text { transportation decisionmakers, officials, and staff. Retrieved } \\
\text { from } \\
\text { http://www.fhwa.dot.gov/planning/publications/briefing_boo } \\
\text { k/fhwahep15048.pdf. } \\
\text { - Rall, J., Wheet, A., Farber, N. J., \& Reed, J. B. (2011). } \\
\text { Transportation governance and finance: A 50-state review of } \\
\text { state legislatures and departments of transportation. National } \\
\text { Conference of State Legislatures. AASHTO Center for } \\
\text { Excellence in Project Finance. Retrieved from } \\
\text { http://www.ncsl.org/documents/transportation/FULL- } \\
\text { REPORT.pdf. } \\
\text { o Pages 39-163 “State Profiles” } \\
\text { Federal Highway Administration. (2011). Environmental } \\
\text { justice emerging trends and best practices guidebook. } \\
\text { Retrieved from } \\
\text { http://www.fhwa.dot.gov/environment/environmental_justice } \\
\text { /resources/guidebook/ejguidebook110111.pdf. } \\
\text { Executive Order 12898. (1994). Federal actions to address } \\
\text { environmental justice in minority populations and low- } \\
\text { income populations. Retrieved from } \\
\text { https://www.archives.gov/federal-register/executive- }\end{array}$ \\
\hline
\end{tabular}




\begin{tabular}{|c|c|}
\hline & $\begin{array}{l}\text { orders/pdf/12898.pdf. } \\
\text { - Executive Order 13166. (2000). Improving access to services } \\
\text { for persons with limited English proficiency. Retrieved from } \\
\text { http://www.gpo.gov/fdsys/pkg/FR-2000-08-16/pdf/00- } \\
\text { 20938.pdf. }\end{array}$ \\
\hline Lecture Content & $\begin{array}{l}\text { - Roles of the federal, state, and local government } \\
\text { - Metropolitan Planning Organizations } \\
\text { o History } \\
\text { o Function } \\
\text { - Institutional challenges } \\
\text { - Transportation stakeholders and public involvement }\end{array}$ \\
\hline Assessment/Activities & $\begin{array}{l}\text { - Activity: Public meeting role play (students will be given } \\
\text { roles and information prior to class)(1 hour) }\end{array}$ \\
\hline $\begin{array}{l}\text { Instructional } \\
\text { Resources }\end{array}$ & 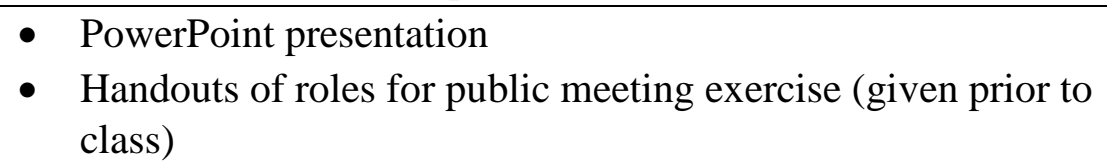 \\
\hline
\end{tabular}

\section{Instructor's Notes}

- Discussion questions:

o What agencies and organizations are involved in the governance of transportation in this region?

o What are their roles?

- In-class activity: Public meeting role play

o See the handout associated with this in-class exercise (Appendix C: Public Meeting Role Play Handout). You will serve as a mediator during the exercise. Your duties will include:

- Keeping participants on track with their roles and discussion points.

- Ensuring the meeting simulation does not exceed the time limit set for the exercise while guaranteeing that all participants are engaged in the meeting discussion. 


\section{MODULE 4: MULTIMODAL PLANNING CONCEPTS AND PROCESS}

\begin{tabular}{|c|c|}
\hline \multicolumn{2}{|l|}{ Module 4} \\
\hline Topic & Multimodal Planning Concepts and Process \\
\hline Objectives & $\begin{array}{l}\text { Students will be able to understand the transportation planning process, } \\
\text { how it has changed over time, and critiques of the conventional "auto- } \\
\text { centric" approach to transportation planning. } \\
\text { At the end of this lesson, students will be able to: } \\
\text { - Identify common steps of the planning process. } \\
\text { - Describe and critique the conventional planning process as it } \\
\text { relates to contemporary multimodal planning. } \\
\text { - Understand the importance of aligning state, regional, local, and } \\
\text { modal plans. }\end{array}$ \\
\hline Assignments Due & Assignment 1: Reading reflection \#1 due \\
\hline Readings & $\begin{array}{l}\text { Required } \\
\text { - Tumlin, J. (2012). Sustainable transportation planning: Tools } \\
\text { for creating vibrant, healthy, and resilient communities. } \\
\text { Hoboken, NJ: John Wiley \& Sons, Inc. } \\
\text { o Chapter 1: Introduction } \\
\text { o Chapter 2: Sustainable Transportation } \\
\text { - Litman, T. (2014). Introduction to multi-modal transportation } \\
\text { planning: Principles and practices. Retrieved from } \\
\text { http://www.vtpi.org/multimodal_planning.pdf. } \\
\text { Boarnet, M.G. (2008). Transportation infrastructure and } \\
\text { sustainable development: New planning approaches for urban } \\
\text { growth. ACCESS, 33, 27-33. Retrieved from } \\
\text { http://www.uctc.net/access/33/Access\%2033\%20-\%2005\%20- } \\
\text { \%20New\%20Planning\%20Approaches.pdf. } \\
\text { Taylor, B. D. (2002). Rethinking traffic congestion. ACCESS, } \\
\text { 21, 8-16. Retrieved from } \\
\text { http://www.uctc.net/access/21/Access\%2021\%20-\%2003\%20- } \\
\text { \%20Rethinking\%20Congestion.pdf. } \\
\text { Optional } \\
\text { Hanson, S. \& Guiliano, G. (Eds.) (2004). The geography of } \\
\text { urban transportation. New York: Guilford Press. } \\
\text { o Chapter 5: The Urban Transportation Planning Process } \\
\text { o Chapter 6: Reflections on the Planning Process } \\
\text { U.S. Department of Transportation. (2012). Best planning } \\
\text { practices: Metropolitan transportation plans. Retrieved from } \\
\text { https://www.planning.dot.gov/documents/BestPlanningPractice } \\
\text { s_MTP.pdf. } \\
\end{array}$ \\
\hline Lecture Content & $\begin{array}{l}\text { - Overview of the transportation planning process } \\
\text { - Criticisms of the conventional transportation planning process } \\
\text { - Key concepts and characteristics of contemporary transportation }\end{array}$ \\
\hline
\end{tabular}




\begin{tabular}{|l|c|}
\hline & \multicolumn{2}{|c|}{ planning } \\
& - Regional and intergovernmental coordination \\
\hline Assessment/Activities & $\begin{array}{c}\text { Activity } \\
0\end{array}$ \\
\hline $\begin{array}{l}\text { Instructional } \\
\text { Resources }\end{array}$ & $\begin{array}{c}\text { PowerPoint presentation } \\
0 \text { Contemporary Planning Concepts \& Process }\end{array}$ \\
\hline
\end{tabular}




\section{MODULE 5: TRANSPORTATION, LAND USE AND URBAN FORM}

\begin{tabular}{|c|c|}
\hline \multicolumn{2}{|l|}{ Module 5} \\
\hline Topic & Transportation, Land Use and Urban Form \\
\hline Objectives & $\begin{array}{l}\text { This lesson explores the various ways in which transportation and land } \\
\text { use interrelate, and the corresponding implications for urban form and } \\
\text { modal options. } \\
\text { After completing this lesson students will be able to: } \\
\text { - Understand how transportation and land use are interrelated } \\
\text { and explore tools used to identify these connections. } \\
\text { - Identify how land use and transportation planning practices } \\
\text { influence urban form. } \\
\text { - Understand the relative influence of changes in the built } \\
\text { environment on travel behavior. } \\
\text { - Understand the role of scenario planning/visioning processes } \\
\text { in testing and shaping transportation and land use alternatives. } \\
\text { Understand tools used to transition already-developed } \\
\text { communities or regions from auto-centric to multimodal } \\
\text { mobility. }\end{array}$ \\
\hline Assignments Due & $\mathrm{N} / \mathrm{A}$ \\
\hline Readings & $\begin{array}{l}\text { Required } \\
\text { - Transportation Research Board. (2009). Special report 298: } \\
\text { Driving and the built environment: The effects of compact } \\
\text { development on motorized travel, energy use, and CO } 2 \\
\text { emissions. Retrieved from } \\
\text { http://onlinepubs.trb.org/Onlinepubs/sr/sr298.pdf. } \\
\text { o Chapter 2: Trends in Development Patterns } \\
\text { o Chapter 3: Impacts of Land Use Patterns on Vehicle } \\
\quad \text { Miles Traveled: Evidence from the Literature } \\
\text { Shoup, D. C. (1999). The trouble with minimum parking } \\
\text { requirements. Transportation Research Part A: Policy and } \\
\text { Practice, 33(7), 549-574. Retrieved from } \\
\text { http://shoup.bol.ucla.edu/Trouble.pdf. } \\
\text { Seggerman, K. \& Williams, K. (2014). Managing the impacts } \\
\text { of bypasses on small and medium-sized communities in } \\
\text { Florida. Transportation Research Record: Journal of the } \\
\text { Transportation Research Board, 2453, 46-53. Retrieved from } \\
\text { http://trrjournalonline.trb.org/doi/pdf/10.3141/2453-06. } \\
\text { Federal Highway Administration. (2011). FHWA Scenario } \\
\text { planning guidebook. Retrieved from } \\
\text { https://www.fhwa.dot.gov/planning/scenario_and_visualizatio } \\
\text { n/scenario_planning/scenario_planning_guidebook/guidebook. } \\
\text { pdf. }\end{array}$ \\
\hline
\end{tabular}




\begin{tabular}{|c|c|}
\hline & $\begin{array}{l}\text { Optional } \\
\text { - Ewing, R. \& Cervero, R. (2010). Travel and the built } \\
\text { environment: A meta-analysis. Journal of the American } \\
\text { Planning Association, 76(3), 265-294. Retrieved from } \\
\text { http://reconnectingamerica.org/assets/Uploads/travelbuiltenvir } \\
\text { onment20100511.pdf. }\end{array}$ \\
\hline Lecture Content & $\begin{array}{l}\text { - Land use and transportation integration challenges } \\
\text { o System wide } \\
\text { o Corridor } \\
\text { o Transitioning from auto-centric to multimodal mobility } \\
\text { in developed areas } \\
\text { o Retrofitting places } \\
\text { - Indirect impacts of transportation on land use } \\
\text { o Transportation and land use cycle/bypass impacts } \\
\text { o Nature and costs of sprawl development } \\
\text { o Corridor access issues and impacts } \\
\text { - Built environment factors/features impacting multimodal } \\
\text { options (5 “Ds,” etc.) } \\
\text { o Destination accessibility/centricity/core } \\
\text { o Density } \\
\text { o Design/connectivity, street design, site design } \\
\text { o Diversity/land use mix } \\
\text { o Distance to transit } \\
\text { - Scenario planning and visioning } \\
\text { - Surface parking }\end{array}$ \\
\hline Assessment/Activities & - Housing and Transportation Affordability Index \\
\hline $\begin{array}{l}\text { Instructional } \\
\text { Resources }\end{array}$ & $\begin{array}{l}\text { - } \begin{array}{l}\text { PowerPoint presentation } \\
\text { - Housing + Transportation Affordability Index } \\
0 \text { http://htaindex.cnt.org/ }\end{array} \\
\end{array}$ \\
\hline
\end{tabular}

\section{Instructor's Notes}

- In-class exercise: Housing and Transportation Affordability Index

o This exercise is intended to familiarize students with how transportation costs impact overall cost of living.

o Access the index using the link provided in the lesson plan. Explore the website, compare different cities, and discuss your findings as a group. 


\section{MODULE 6: TRANSPORTATION AND LAND USE PLANNING BEST PRACTICES}

\begin{tabular}{|c|c|}
\hline \multicolumn{2}{|l|}{ Module 6} \\
\hline Topic & Transportation and Land Use Planning Best Practices \\
\hline Objectives & $\begin{array}{l}\text { This lesson continues to develop the concepts introduced in the } \\
\text { previous module with an emphasis on contemporary best practices for } \\
\text { integrating land use and transportation planning to support multimodal } \\
\text { transportation options. At the end of this lesson students will be able to: } \\
\text { - Understand best practices for integration of land use and } \\
\text { transportation planning. } \\
\text { - Understand key tenets of network and corridor planning. } \\
\text { - Understand roadway functional classification and how it has } \\
\text { changed to address livability and land use context. }\end{array}$ \\
\hline Assignments Due & N/A \\
\hline Readings & 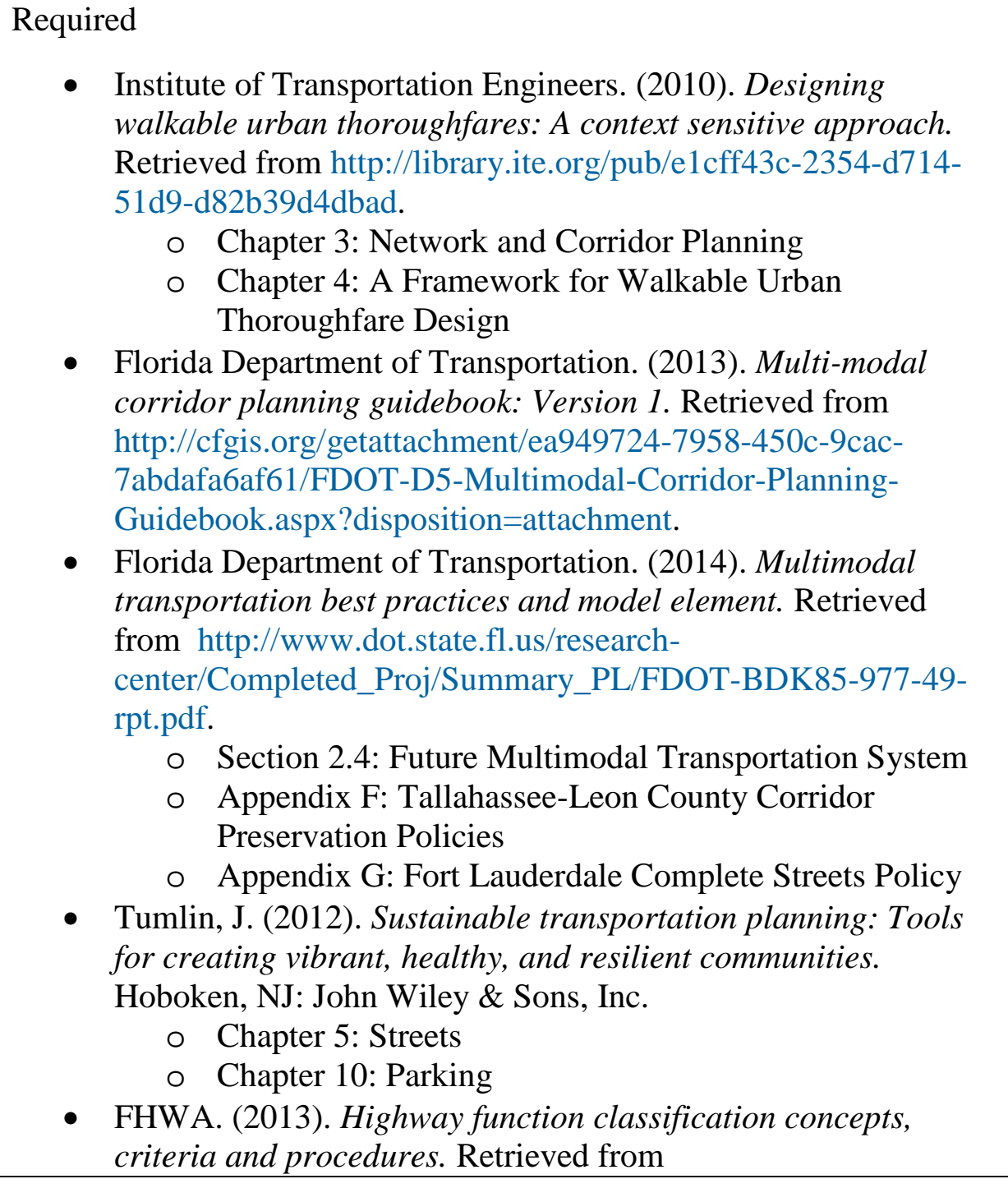 \\
\hline
\end{tabular}




\begin{tabular}{|c|c|}
\hline & $\begin{array}{l}\text { http://www.fhwa.dot.gov/planning/processes/statewide/related/ } \\
\text { highway_functional_classifications/fcauab.pdf. } \\
\text { - Federal Highway Administration.(2015). Road diet desk } \\
\text { reference. Retrieved from } \\
\text { http://safety.fhwa.dot.gov/road_diets/desk_ref/sa_15_046.pdf. } \\
\text { - Federal Highway Administration. (2015). Proven safety } \\
\text { countermeasures: Roundabouts. Retrieved from } \\
\text { http://safety.fhwa.dot.gov/provencountermeasures/fhwa_sa_12_ } \\
\text { 005.pdf. } \\
\text { Optional } \\
\text { City of Boston. (2013). Boston complete streets: Design } \\
\text { guidelines. Retrieved from } \\
\text { http://bostoncompletestreets.org/pdf/2013/BCS_Guidelines_Lo } \\
\text { wRes.pdf. }\end{array}$ \\
\hline Lecture Content & 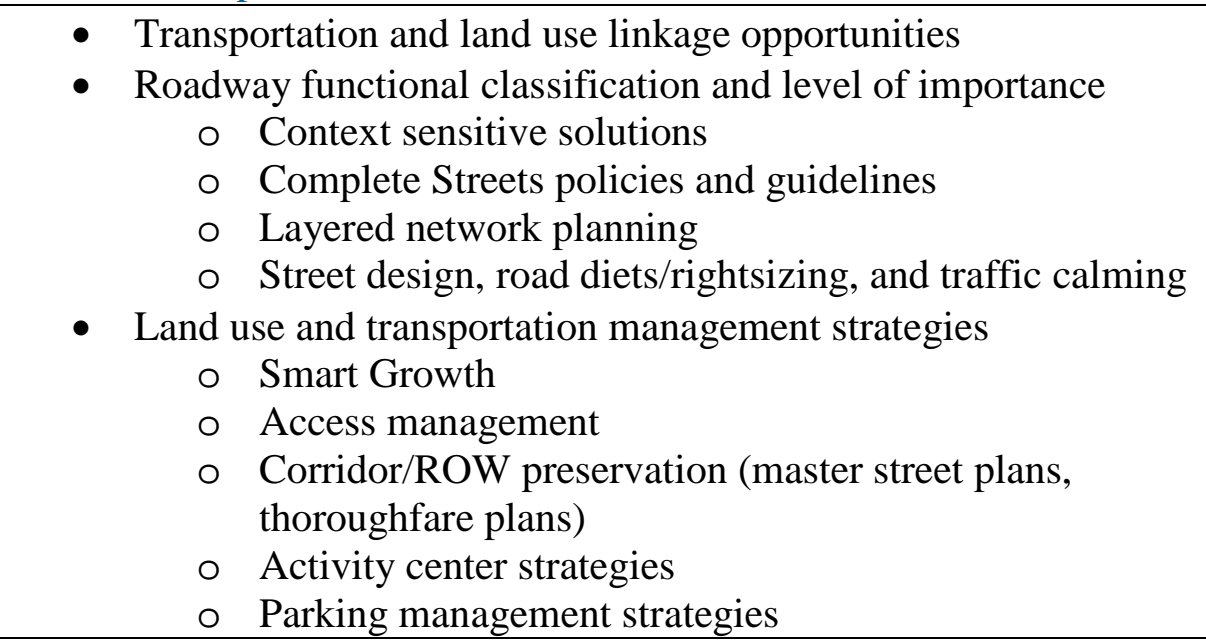 \\
\hline Assessment/Activities & $\begin{array}{l}\text { - View and discuss DRPT Multimodal Systems Guidelines Video } \\
\text { (6 minute video) }\end{array}$ \\
\hline $\begin{array}{l}\text { Instructional } \\
\text { Resources }\end{array}$ & $\begin{array}{l}\text { - PowerPoint presentation } \\
\text { o Transportation and Land Use Planning Best Practices } \\
\text { - Florida Department of Transportation. (2013) Mobility review } \\
\text { guide. Retrieved from } \\
\text { http://www.dot.state.fl.us/planning/systems/programs/sm/mobili } \\
\text { ty/cutr\%20updated\%20mobility\%20review\%20guide.pdf. } \\
\text { - DRPT Multimodal Systems Guidelines Video (6 minutes): } \\
\text { https://vimeo.com/62260155 }\end{array}$ \\
\hline
\end{tabular}

\section{Instructor's Notes}

- In-class activity: DRPT Multimodal Systems Guidelines

o View the video via the link provided in the lesson plan. Discuss. 


\subsubsection{Module 7: Travel Patterns and Behavior}

\begin{tabular}{|c|c|}
\hline \multicolumn{2}{|l|}{ Module 7} \\
\hline Topic & Travel Patterns and Behavior \\
\hline Objectives & $\begin{array}{l}\text { This lesson synthesizes research findings to understand if travel } \\
\text { behavior is influenced by physical characteristics of the environment, } \\
\text { attitudes and lifestyles, or both. At the end of this lesson students will } \\
\text { be able to: } \\
\text { - Understand trends in travel. } \\
\text { - Identify factors that influence travel behavior. } \\
\text { - Recommend strategies to achieve the desired changes in } \\
\text { travel behavior. }\end{array}$ \\
\hline Assignments Due & Assignment 2: Reading reflection \#2 due \\
\hline Readings & 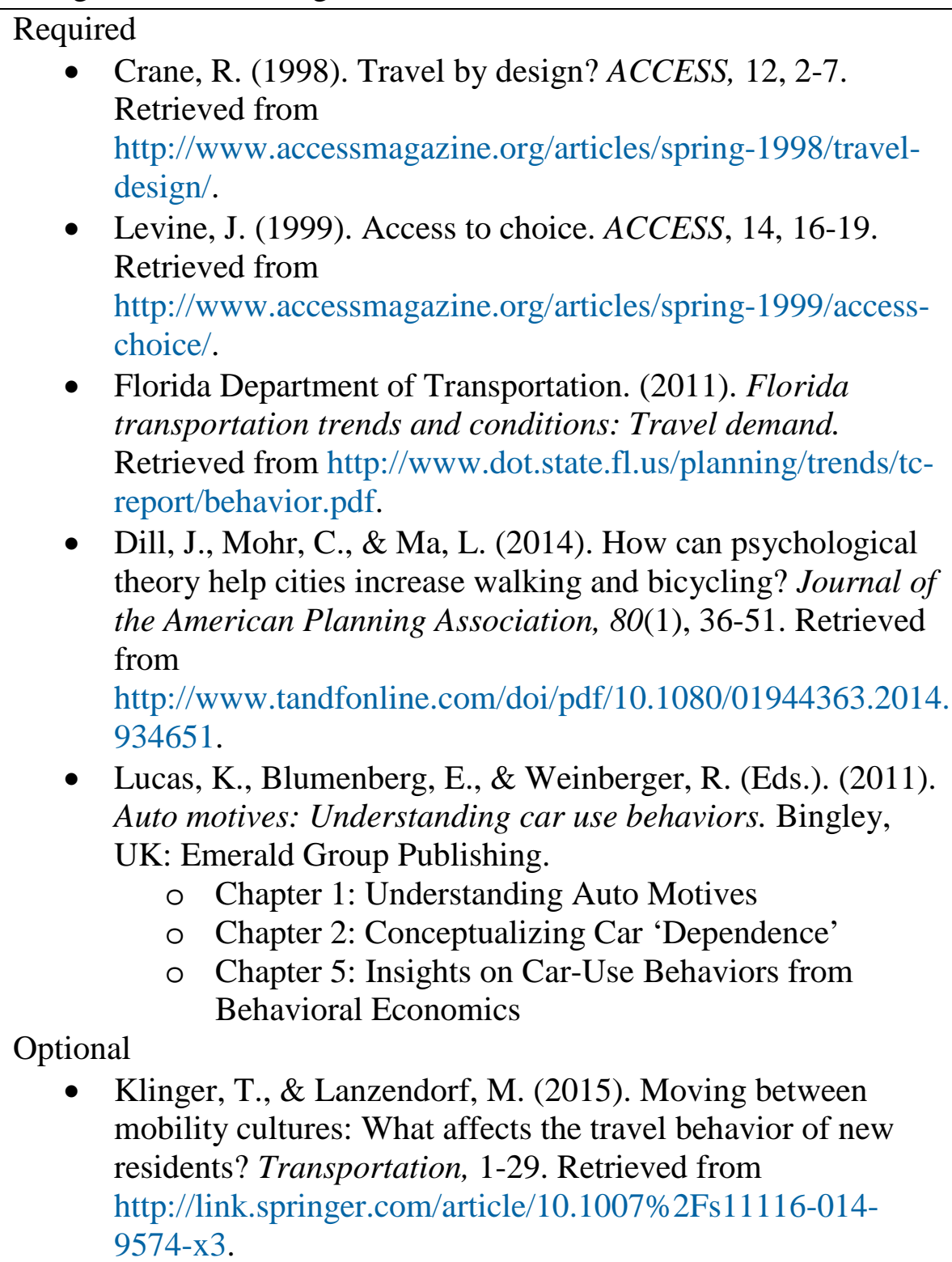 \\
\hline Lecture Content & - $\quad$ Theory of planned behavior \\
\hline
\end{tabular}




\begin{tabular}{|c|c|}
\hline & $\begin{array}{ll}\text { - } & \text { Theoretical formulation vs observed behavior } \\
\text { Factors that affect travel behavior } \\
\text { o } & \text { Sociodemographics } \\
\text { o } & \text { Built environment } \\
\text { o } & \text { Attitudes } \\
\text { o } & \text { Social norms } \\
\text { o } & \text { Perceptions of safety } \\
\text { - Travel decisions } \\
\text { o Activity generation and allocation } \\
\text { o } & \text { Scheduling and participation } \\
\text { o } & \text { Actual mode choice or constrained preference } \\
\text { - Behavior change strategies } \\
\text { o Time-cost (incl. toll facilities, etc.) } \\
\text { o Land use design } \\
\text { o Availability of choice and intermodal connectivity } \\
\text { o Voluntary programs (e.g., social marketing strategies } \\
\\
\text { such as incentives, prompts, social norming, social } \\
\text { diffusion, communication) }\end{array}$ \\
\hline Assessment/Activities & - Discuss reading reactions \\
\hline $\begin{array}{l}\text { Instructional } \\
\text { Resources }\end{array}$ & $\begin{array}{l}\text { - PowerPoint presentation } \\
\text { o TBD }\end{array}$ \\
\hline
\end{tabular}

\section{Instructor's Notes}

- Lucas, Blumenberg and Weinberger reading provides students with an in-depth understanding of the motivations and decision processes that drive the public's overwhelming preference for the car as the primary means of transportation. This book may be available through the university/college library. Otherwise, students may need to purchase it. Alternatively, upon the instructor's request, many libraries will scan hard copies of the text and make them available for courses.

- In-class activity: Discuss reading reactions

o Encourage students to discuss their reading reactions. 
MODULE 8: NON-MOTORIZED TRANSPORTATION: WALKING AND BICYCLING

\begin{tabular}{|c|c|}
\hline \multicolumn{2}{|l|}{ Module 8} \\
\hline Topic & Non-Motorized Transportation: Walking and Bicycling \\
\hline Objectives & $\begin{array}{l}\text { This lesson reviews the role of bicycling and walking as key forms of } \\
\text { active transportation in a multimodal system. The benefits of } \\
\text { bicycling and walking, infrastructure needs, and planning and policy } \\
\text { issues will be discussed. Best practices in planning for walking and } \\
\text { bicycling will also be conveyed. } \\
\text { At the end of this lesson students will be able to: } \\
\text { - Explain the social, economic, health and environmental } \\
\text { benefits of walking and biking. } \\
\text { - Demonstrate their understanding of best practices in planning } \\
\text { for non-motorized transportation. }\end{array}$ \\
\hline Assignments Due & Assignment 3: Walkability assessment due \\
\hline Readings & $\begin{array}{l}\text { Required } \\
\text { - Tumlin, J. (2012). Sustainable transportation planning: Tools } \\
\text { for creating vibrant, healthy, and resilient communities. } \\
\text { Hoboken, NJ: John Wiley \& Sons, Inc. } \\
\text { o Chapter 6: Pedestrians } \\
\text { o Chapter 7: Bicycles } \\
\text { - Initiative for Bicycle and Pedestrian Innovation. (2012). } \\
\text { Creating walkable + bikeable communities: A user guide to } \\
\text { developing pedestrian and bicycle master plans. Retrieved } \\
\text { from } \\
\text { http://www.pdx.edu/ibpi/sites/www.pdx.edu.ibpi/files/IBPI\% } \\
\text { 20Master\%20Plan\%20Handbook\%20FINAL\%20(7.27.12).p } \\
\text { df. } \\
\text { o Chapter 1: Introduction } \\
\text { o Chapter 2: History and Evolution of Pedestrian and } \\
\text { Bicycle Master Planning } \\
\text { o Chapter 3: Preparing for the Planning Process } \\
\text { o Chapter 7: Establishing a Fact Base } \\
\text { Plan Recommendations } \\
\text { Florida Department of Transportation. (2014). Multimodal } \\
\text { transportation best practices and model element. Retrieved } \\
\text { from http://www.dot.state.fl.us/research- } \\
\text { center/Completed_Proj/Summary_PL/FDOT-BDK85-977- } \\
\text { 49-rpt.pdf. } \\
\text { o Chapter 2: Model Element for Urbanized Areas (only } \\
\text { read sections related to bicycles and pedestrians) } \\
\text { G.d.). Four types of cyclists. Retrieved from }\end{array}$ \\
\hline
\end{tabular}




\begin{tabular}{|c|c|}
\hline & $\begin{array}{l}\text { https://www.portlandoregon.gov/transportation/44597?a=237 } \\
\text { 507. }\end{array}$ \\
\hline Lecture Content & $\begin{array}{l}\text { - History of bicycle/pedestrian planning } \\
\text { - Overview of bicycle/pedestrian planning process } \\
\text { - Bicycle/pedestrian planning methods }\end{array}$ \\
\hline Assessment/Activities & $\begin{array}{l}\text { - Activity } \\
0 \text { View and discuss Protected Bike Lane video (15 } \\
\text { minutes) } \\
\text { - Activity } \\
\text { o View before-and-after photos in PowerPoint and } \\
\text { discuss observations } \\
\text { - Discuss results of walkability and bikeability assessment }\end{array}$ \\
\hline $\begin{array}{l}\text { Instructional } \\
\text { Resources }\end{array}$ & $\begin{array}{l}\text { - PowerPoint presentation } \\
\text { o Bicycle and Pedestrian Planning } \\
\text { - Protected Bike Lane video: } \\
\text { http://www.wired.com/2014/06/a-new-bike-lane-design-that- } \\
\text { could-make-biking-more-popular-and-save-lives/\#slide-1 } \\
\text { - Florida Department of Transportation. (2013) Mobility review } \\
\text { guide. Retrieved from } \\
\text { http://www.dot.state.fl.us/planning/systems/programs/sm/mo } \\
\text { bility/cutr\%20updated\%20mobility\%20review\%20guide.pdf. } \\
\text { o Walkability and Bikeability Checklists }\end{array}$ \\
\hline
\end{tabular}

\section{Instructor's Notes}

- In-class activity: Protected Bike Lane video

o View the video via the link provided in the lesson plan. Discuss.

- In-class activity: Before and After

o View before-and-after photos in PowerPoint (slides 30 and 31) and discuss.

- In-class activity: Discuss walkability assessment

o Encourage students to discuss their findings from the walkability assessment. 


\section{MODULE 9: TRANSIT AND LAND USE}

\begin{tabular}{|c|c|}
\hline \multicolumn{2}{|l|}{ Module 9} \\
\hline Topic & Transit and Land Use \\
\hline Objectives & $\begin{array}{l}\text { This lesson will provide students with a comprehensive overview of } \\
\text { the various types of public transportation, criteria for implementing } \\
\text { these modes, and best planning practices relative to public } \\
\text { transportation. } \\
\text { At the end of this lesson students will be able to: } \\
\text { - Recognize the importance of the availability of public transit. } \\
\text { - Determine best planning practices and strategies for } \\
\text { reinforcing public transportation. }\end{array}$ \\
\hline Assignments Due & Assignment 4: Transit experience report due \\
\hline Readings & $\begin{array}{l}\text { Required } \\
\text { - Tumlin, J. (2012). Sustainable transportation planning: Tools } \\
\text { for creating vibrant, healthy, and resilient communities. } \\
\text { Hoboken, NJ: John Wiley \& Sons. Inc. } \\
\text { o Chapter 8: Transit } \\
\text { o Chapter 12: Stations and Station Areas } \\
\text { - City of Seattle. (2008). Seattle urban mobility plan briefing } \\
\text { book. Retrieved from } \\
\text { http://www.seattle.gov/transportation/briefingbook.htm. } \\
\text { o Chapter 9: Best Practices in Transit } \\
\text { City of San Diego. (1992). Transit-oriented development } \\
\text { design guidelines. Retrieved from } \\
\text { http://www.sandiego.gov/planning/documents/pdf/trans/todg } \\
\text { uide.pdf. } \\
\text { Florida Department of Transportation. (2011). A framework } \\
\text { for TOD in Florida. Retrieved from } \\
\text { http://www.reconnectingamerica.org/assets/Uploads/201103F } \\
\text { loridaTODFramework.pdf. } \\
\text { o Chapter 1: Introduction } \\
\text { o Chapter 2: Integrated Transit and Land Use Planning } \\
\text { Florida Department of Transportation. (2014). Multimodal } \\
\text { transportation best practices and model element. Retrieved } \\
\text { from http://www.dot.state.fl.us/research- } \\
\text { center/Completed_Proj/Summary_PL/FDOT-BDK85-977- } \\
\text { 49-rpt.pdf. } \\
\text { o Chapter 2 (sections relative to public transportation) } \\
\text { Florida Department of Transportation. (2012). Florida TOD } \\
\text { guidebook. Retrieved from } \\
\text { http://formbasedcodes.org/content/uploads/2014/03/florida- } \\
\text { tod-guidebook.pdf. } \\
\text { Optional }\end{array}$ \\
\hline
\end{tabular}




\begin{tabular}{|c|c|}
\hline & $\begin{array}{l}\text { - Tomer, A., Kneebone, E., Puentes, R., \& Berube, A. (2011). } \\
\text { Missed opportunity: Transit and jobs in metropolitan } \\
\text { America. Brookings Institution. Retrieved from } \\
\text { http://www.brookings.edu/ /media/research/files/reports/201 } \\
\text { 1/5/12-jobs-and-transit/0512_jobs_transit.pdf. }\end{array}$ \\
\hline Lecture Content & $\begin{array}{l}\text { - Types of public transportation and implementation criteria } \\
\text { - Integrating public transportation plans } \\
\text { - Transit and land use planning best practices overview } \\
\text { - Challenges for transit } \\
\text { o securing adequate, dedicated sources of funding for } \\
\text { operations and maintenance } \\
\text { o retrofitting auto-centric areas to increase transit } \\
\text { availability, planning for transit in regions with } \\
\text { multiple centers } \\
\text { o avoiding displacement of lower-income populations } \\
\text { with implementation of premium-type transit services } \\
\text { o providing a variety of housing choices around transit } \\
\text { stations }\end{array}$ \\
\hline Assessment/Activities & $\begin{array}{l}\text { - Review the Center for Transit Oriented Development website } \\
\text { - Discuss experiences of riding local transit }\end{array}$ \\
\hline $\begin{array}{l}\text { Instructional } \\
\text { Resources }\end{array}$ & 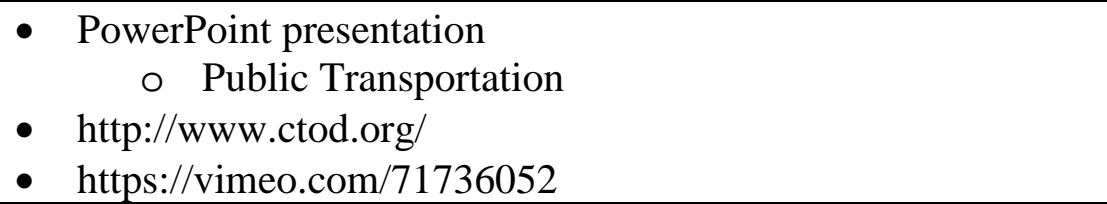 \\
\hline
\end{tabular}

\section{Instructor's Notes}

- In-class activity: TOD website

o During the PowerPoint presentation (slide \#21), introduce students to the Center for Transit-Oriented Development website http://www.ctod.org/. Guide Students through important tabs including:

- TOD-cation http://www.ctod.org/tod-ucation.php

- Webinars

- Conference presentations

- TOD 100 and 200 Series

- Fact-Based Research and Tools http://www.ctod.org/research-tools.php

- The national TOD database

- The performance-based TOD typology tool

o Encourage students to explore the website further on their own

- In-class activity: Transit experience

o Encourage students to discuss the findings from their transit experience report. 


\section{MODULE 10: FREIGHT AND GOODS MOVEMENT}

\begin{tabular}{|c|c|}
\hline \multicolumn{2}{|l|}{ Module 10} \\
\hline Topic & Freight and Goods Movement \\
\hline Objectives & $\begin{array}{l}\text { This lesson provides an overview of the movement of goods and } \\
\text { how to integrate freight considerations into the multimodal } \\
\text { transportation planning process. } \\
\text { At the end of this lesson students will be able to: } \\
\text { - Understand the role of goods movement in multimodal } \\
\text { transportation planning. } \\
\text { - Understand the importance of freight to the local and } \\
\text { regional economy. } \\
\text { Identify multimodal planning best practices relative to } \\
\text { freight. }\end{array}$ \\
\hline Assignments Due & $\mathrm{N} / \mathrm{A}$ \\
\hline Readings & $\begin{array}{l}\text { Required } \\
\text { - Giuliano, G., O’Brien, T., Dablanc, L., \& Holliday, K. } \\
\text { (2013). NCFRP report 23: Synthesis of freight research in } \\
\text { urban transportation planning. Transportation Research } \\
\text { Board of the National Academies: Washington, D.C. } \\
\text { Retrieved from } \\
\text { http://onlinepubs.trb.org/onlinepubs/ncfrp/ncfrp_rpt_023.pdf } \\
\text { - Florida Department of Transportation. (2013). Florida freight } \\
\text { mobility and trade plan policy element: Executive summary. } \\
\text { Retrieved from } \\
\text { http://www.freightmovesflorida.com/docs/default- } \\
\text { source/fmtp-freight-information/freight-mobility-and-trade- } \\
\text { plan-policy-element-executive-summary_2013-06- } \\
\text { 19.pdf?sfvrsn=0. } \\
\text { City of Seattle. (2008). Seattle urban mobility plan briefing } \\
\text { book. Retrieved from } \\
\text { http://www.seattle.gov/transportation/briefingbook.htm. } \\
\text { o Chapter 10: Best Practices in Freight Movement } \\
\text { Federal Highway Administration. (2012). Freight and land } \\
\text { use handbook. Retrieved from } \\
\text { http://www.ops.fhwa.dot.gov/publications/fhwahop12006/fh } \\
\text { wahop12006.pdf. } \\
\text { o Executive Summary } \\
\text { o Chapter 3: Freight Land Use and Sustainability } \\
\text { Hanson, S. \& Guiliano, G. (Eds.) (2004). The geography of } \\
\text { urban transportation. New York: Guilford Press. } \\
\text { o Chapter 2: City Interactions: The Dynamics of } \\
\text { Opassenger and Freight Flows }\end{array}$ \\
\hline
\end{tabular}




\begin{tabular}{|l|ll|}
\hline Lecture Content & $\begin{array}{l}\text { Freight trends relative to multimodal planning } \\
\text { - }\end{array}$ & $\begin{array}{l}\text { Issues in current practice (e.g., land use compatibility, } \\
\text { livability, economic trends in the supply chain) }\end{array}$ \\
& - $\begin{array}{l}\text { Multimodal land use and transportation planning best } \\
\text { practices relative to freight }\end{array}$ \\
\hline Assessment/Activities & $\bullet$ & The exportation process \\
\hline $\begin{array}{l}\text { Instructional } \\
\text { Resources }\end{array}$ & $\begin{array}{l}\text { PowerPoint presentation } \\
\text { o Freight and Goods Movement }\end{array}$ \\
\hline
\end{tabular}

\section{Instructors Notes}

- In-class activity: The Exportation Process: Supply Chains: From Producer to Consumer o Access the activity handout at http://rightmoves.tdtvictoria.org.au/pdf/Activity5.pdf o Follow the instructions on the handout. Discuss. 


\section{MODULE 11: TRANSPORTATION DEMAND AND SYSTEMS MANAGEMENT}

\begin{tabular}{|c|c|}
\hline \multicolumn{2}{|l|}{ Module 11} \\
\hline Topic & Transportation Demand and Systems Management \\
\hline Objectives & $\begin{array}{l}\text { This lesson familiarizes students with policies, programs and } \\
\text { services designed to help reduce vehicle miles of travel, reduce delay } \\
\text { and energy consumption, and increase safety and efficiency of the } \\
\text { multimodal transportation system. } \\
\text { At the end of this lesson students will be able to: } \\
\text { - Understand contemporary methods to manage multimodal } \\
\text { transportation system demand and potential benefits of those } \\
\text { strategies, technologies and techniques to increase efficiency. }\end{array}$ \\
\hline Assignments Due & Assignment 5: Technique report due \\
\hline Readings & $\begin{array}{l}\text { Required } \\
\text { Tumlin, J. (2012). Sustainable transportation planning: Tools } \\
\text { for creating vibrant, healthy, and resilient communities. } \\
\text { Hoboken, NJ: John Wiley \& Sons. Inc. } \\
\text { o Chapter 11: Car Sharing } \\
\text { o Chapter 13: Transportation Demand Management } \\
\text { - Federal Highway Administration. (2012). Creating an } \\
\text { effective program to advance transportation system } \\
\text { management and operations. Retrieved from } \\
\text { http://www.camsys.com/pubs/fhwahop12003.pdf. } \\
\text { Martin, E. \& Shaheen, S. (2011). The impacts of car sharing } \\
\text { on household vehicle ownership. ACCESS, 38, 22-27. } \\
\text { Retrieved from http://www.accessmagazine.org/wp- } \\
\text { content/uploads/sites/7/2015/06/access38.pdf. } \\
\text { Shaheen, S. \& Guzman, S. (2011). Worldwide bikesharing. } \\
\text { ACCESS, 39, 22-27. Retrieved from } \\
\text { http://www.accessmagazine.org/wp- } \\
\text { content/uploads/sites/7/2015/06/access39.pdf. } \\
\text { City of Seattle. (2008). Seattle urban mobility plan briefing } \\
\text { book. Retrieved from } \\
\text { http://www.seattle.gov/transportation/briefingbook.htm. } \\
\text { o Chapter 7: Best Practices in Travel Demand } \\
\text { Management } \\
\text { - } \\
\text { Victoria Transport Policy Institute. (2014). Online } \\
\text { transportation demand management encyclopedia. Retrieved } \\
\text { from http://www.vtpi.org/tdm/ } \\
\text { Institution Press. } \\
\text { Optionalic congestion. Washington, D.C.: Brookings } \\
\text { - }\end{array}$ \\
\hline
\end{tabular}




\begin{tabular}{|c|c|}
\hline & $\begin{array}{cl}\text { o } & \text { Chapter 6: Strategies for Reducing Congestion and } \\
& \text { Four Basic Principles of Traffic } \\
\text { o } & \text { Chapter 7: Reducing Incident-Caused Congestion } \\
\end{array}$ \\
\hline Lecture Content & $\begin{array}{l}\text { - Transportation demand management } \\
\text { o Definition } \\
\text { o Techniques } \\
\text { - Collaborative consumption models: car sharing, bike sharing } \\
\text { o Bikeshare } \\
\text { o Carshare } \\
\text { - System management and operations } \\
\text { o ITS adaptive signals } \\
\text { o Bluetooth detection } \\
\text { o Open-source multimodal trip planning }\end{array}$ \\
\hline Assessment/Activities & N/A \\
\hline $\begin{array}{l}\text { Instructional } \\
\text { Resources }\end{array}$ & 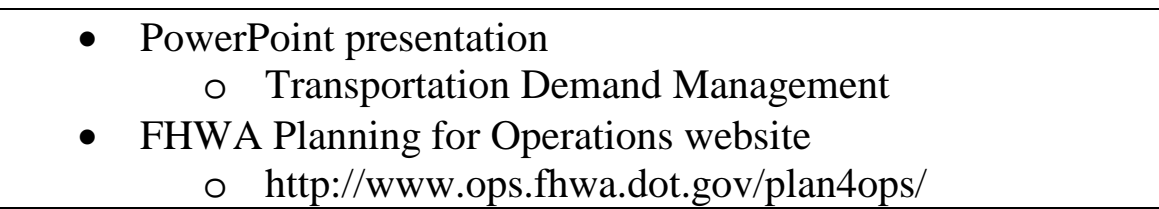 \\
\hline
\end{tabular}




\section{MODULE 12: FUNDING MULTIMODAL TRANSPORTATION SYSTEMS}

\begin{tabular}{|c|c|}
\hline \multicolumn{2}{|l|}{ Module 12} \\
\hline Topic & Funding Multimodal Transportation Systems \\
\hline Objectives & $\begin{array}{l}\text { This lesson familiarizes students with the importance of transportation } \\
\text { to the economy, prosperity, U.S. transportation infrastructure needs, } \\
\text { and proposed investment solutions. Considerations such as financial } \\
\text { feasibility and fiscal sustainability are addressed. } \\
\text { At the end of this lesson students will be able to: } \\
\text { - Understand how transportation impacts the economy. } \\
\text { - Understand how to leverage investments. } \\
\text { - Describe contemporary challenges in transportation funding. } \\
\text { - Identify strategies that have been proposed to generate } \\
\text { revenues for needed transportation projects and programs. }\end{array}$ \\
\hline Assignments Due & N/A \\
\hline Readings & $\begin{array}{l}\text { Required } \\
\text { - U.S. Department of Transportation. (2015). Beyond traffic } \\
\text { 2045: Trends and choices. Retrieved from } \\
\text { https://www.transportation.gov/sites/dot.gov/files/docs/Draft_ } \\
\text { Beyond_Traffic_Framework.pdf. } \\
\text { o "How We Align Decisions and Dollars”, pp.148-187. } \\
\text { - Wachs, M. (2011). Transportation, jobs, and economic growth. } \\
\text { ACCESS, 38, 8-14. Retrieved from } \\
\text { http://www.uctc.net/access/38/access38_transportation_growth } \\
\text {.pdf. } \\
\text { Sciara, G. \& Wachs, M. (2007). Metropolitan transportation } \\
\text { funding: Prospects, progress, and practical considerations. } \\
\text { Public Works Management \& Policy, 12(1), 378-394. } \\
\text { Retrieved from } \\
\text { http://pwm.sagepub.com/content/12/1/378.full.pdf+html. } \\
\text { Shoup, D. (2004). The ideal source of public revenue. Regional } \\
\text { Science and Urban Economics, 34, 753-784. Retrieved from } \\
\text { http://shoup.bol.ucla.edu/IdealSource.pdf. } \\
\text { Federal Highway Administration. (2012). Moving ahead for } \\
\text { progress in the 21st century act (MAP-21): A summary of } \\
\text { highway provisions. Retrieved from } \\
\text { https://www.fhwa.dot.gov/map21/docs/map21_summary_hgw } \\
\text { y_provisions.pdf. } \\
\text { Federal Transit Administration. (2012). Moving ahead for } \\
\text { progress in the 21st century act (MAP-21): A summary of } \\
\text { public transportation provisions. Retrieved from } \\
\text { http://www.fta.dot.gov/documents/MAP21_essay_style_summ } \\
\text { ary_v5_MASTER.pdf. } \\
\text { Optional }\end{array}$ \\
\hline
\end{tabular}




\begin{tabular}{|c|c|}
\hline & $\begin{array}{l}\text { Transportation Research Board. (2011). Special report 303: } \\
\text { Equity of evolving transportation finance mechanisms. } \\
\text { Transportation Research Board of the National Academies: } \\
\text { Washington, D.C. Retrieved from } \\
\text { http://onlinepubs.trb.org/onlinepubs/sr/sr303.pdf. } \\
\text { - Galston, W.A. \& Davis, K. (2012). Setting priorities, meeting } \\
\text { needs: The case for a national infrastructure bank. Governance } \\
\text { Studies at Brookings Institution. Retrieved from } \\
\text { http://www.brookings.edu/ /media/Research/Files/Papers/2012 } \\
\text { /12/13-infrastructure-galston- } \\
\text { davis/1213_infrastructure_galston_davis.pdf?la=en. }\end{array}$ \\
\hline Lecture Content & $\begin{array}{l}\text { - Importance of transportation to the U.S. economy } \\
\text { - Funding sources and challenges with traditional state, regional } \\
\text { and local government sources (gas tax decline, capital funding } \\
\text { vs. operations and maintenance, etc.) } \\
\text { - Alternative funding strategies } \\
\text { - Coordinating and leveraging policies and investments } \\
\text { - } \quad \text { "Fix it first" approach }\end{array}$ \\
\hline Assessment/Activities & N/A \\
\hline $\begin{array}{l}\text { Instructional } \\
\text { Resources and } \\
\text { Equipment }\end{array}$ & $\begin{array}{l}\text { - PowerPoint presentation } \\
\quad \text { o Funding Multimodal Transportation Systems }\end{array}$ \\
\hline
\end{tabular}

\section{Instructor's Notes}

- MAP-21 was replaced by the FAST (Fixing America's Surface Transportation) Act in December 2015. Be sure to note this in the lecture and update the readings and PowerPoint slides when summaries of the law become available. 


\section{MODULE 13: EVALUATING SYSTEM PERFORMANCE}

\begin{tabular}{|c|c|}
\hline \multicolumn{2}{|l|}{ Module 13} \\
\hline Topic & Evaluating System Performance \\
\hline Objectives & $\begin{array}{l}\text { This lesson introduces students to the transportation performance } \\
\text { measures and methods of evaluating system performance. } \\
\text { At the end of this lesson students will be able to: } \\
\text { - Understand limitations of traditional methods of performance } \\
\text { evaluation. } \\
\text { - Identify appropriate performance measures for various aspects } \\
\text { of the multimodal system. } \\
\text { - Identify tools and resources for assessing and reporting on } \\
\text { system performance. } \\
\text { - Understand performance based planning requirements in } \\
\text { MAP-21. }\end{array}$ \\
\hline Assignments Due & N/A \\
\hline Readings & $\begin{array}{l}\text { Required } \\
\text { - Tumlin, J. (2012). Sustainable transportation planning: Tools } \\
\text { for creating vibrant, healthy, and resilient communities. } \\
\text { Hoboken, NJ: John Wiley \& Sons. Inc. } \\
\text { o Chapter 14: Measuring Success } \\
\text { - McCahill, C. \& Ebeling, M. (2015). Tools for measuring } \\
\text { accessibility in an equity framework. Congress for the New } \\
\text { Urbanism 23rd Annual Meeting. Retrieved from } \\
\text { https://www.cnu.org/sites/default/files/ssti_transpo_equity.pdf } \\
\text { Initiative for Bicycle and Pedestrian Innovation. (2012). } \\
\text { Creating walkable + bikeable communities: A user guide to } \\
\text { developing pedestrian and bicycle master plans. Retrieved } \\
\text { from } \\
\text { http://www.pdx.edu/ibpi/sites/www.pdx.edu.ibpi/files/IBPI\%2 } \\
\text { 0Master\%20Plan\%20Handbook\%20FINAL\%20(7.27.12).pdf. } \\
\text { o Chapter 9: Monitoring and Evaluating Performance } \\
\text { U.S. Environmental Protection Agency. (2011). Guide to } \\
\text { sustainable transportation performance measures. Retrieved } \\
\text { from http://www.epa.gov/sites/production/files/2014- } \\
\text { 01/documents/sustainable_transpo_performance.pdf. } \\
\text { Katz, P. (2013). The missing metric. Government Finance } \\
\text { Review, 29(4), 20-32. Retrieved from } \\
\text { http://www.gfoa.org/sites/default/files/GFR_AUG_13_20.pdf. } \\
\text { Optional } \\
\text { Flyvbjerg, B., Skamris Holm, M. K., \& Buhl, S. L. (2005). } \\
\text { How (in) accurate are demand forecasts in public works } \\
\text { projects?: The case of transportation. Journal of the American } \\
\text { Planning Association, 71(2), 131-146. Retrieved from }\end{array}$ \\
\hline
\end{tabular}




\begin{tabular}{|c|c|}
\hline & http://flyvbjerg.plan.aau.dk/Traffic91PRINTJAPA.pdf. \\
\hline Lecture Content & $\begin{array}{l}\text { - } \text { Data sources } \\
\text { - Transportation evaluation tools } \\
\text { - } \text { Accessibility evaluation } \\
\text { - Monitoring performance }\end{array}$ \\
\hline Assessment/Activities & $\mathrm{N} / \mathrm{A}$ \\
\hline $\begin{array}{l}\text { Instructional } \\
\text { Resources }\end{array}$ & - PowerPoint presentation \\
\hline
\end{tabular}

\section{Instructor's Notes}

- A handout of multimodal transportation planning objectives and appropriate measures/indicators is available in Appendix D: Evaluating System Performance Handout. 


\section{MODULE 14: COURSE WRAP-UP}

\begin{tabular}{|l|l|}
\hline Module 14 & Course Wrap-Up \\
\hline Topic & $\begin{array}{l}\text { Students shall present their final papers to the class in a 20-minute } \\
\text { PowerPoint presentation. }\end{array}$ \\
\hline Objectives & Final presentations due \\
\hline Assignments Due & N/A \\
\hline Readings & Student presentations \\
\hline Lecture Content & N/A \\
\hline Assessment/Activities & N/A \\
\hline $\begin{array}{l}\text { Instructional } \\
\text { Resources }\end{array}$ & \\
\hline
\end{tabular}




\section{MODULE 15: COURSE WRAP-UP}

\begin{tabular}{|l|l|}
\hline Module 15 & Course Wrap-Up \\
\hline Topic & $\begin{array}{l}\text { Students shall present their final papers to the class in a 20-minute } \\
\text { PowerPoint presentation. }\end{array}$ \\
\hline Objectives & Final presentations and final papers due \\
\hline Assignments Due & N/A \\
\hline Readings & Student presentations \\
\hline Lecture Content & N/A \\
\hline Assessment/Activities & N/A \\
\hline $\begin{array}{l}\text { Instructional } \\
\text { Resources }\end{array}$ & \\
\hline
\end{tabular}




\subsection{GRADING RUBRICS}

\subsection{COURSE ASSIGNMENTS}

\begin{tabular}{|c|c|c|c|c|}
\hline CATEGORY & Excellent & Good & Fair & Poor \\
\hline Organization & $\begin{array}{l}\text { Information is very } \\
\text { organized with } \\
\text { well-constructed } \\
\text { paragraphs and } \\
\text { subheadings. } \\
\qquad 2 \text { points }\end{array}$ & $\begin{array}{l}\text { Information is } \\
\text { organized with } \\
\text { well-constructed } \\
\text { paragraphs. }\end{array}$ & $\begin{array}{l}\text { Information is } \\
\text { organized, but } \\
\text { paragraphs are not } \\
\text { well-constructed. }\end{array}$ & $\begin{array}{l}\text { The information } \\
\text { appears to be } \\
\text { disorganized. }\end{array}$ \\
\hline $\begin{array}{l}\text { Mechanics } \\
3 \text { points }\end{array}$ & $\begin{array}{l}\text { No grammatical, } \\
\text { spelling or } \\
\text { punctuation errors. }\end{array}$ & $\begin{array}{l}\text { Almost no } \\
\text { grammatical, } \\
\text { spelling or } \\
\text { punctuation errors } \\
\qquad 2 \text { points }\end{array}$ & $\begin{array}{l}\text { A few grammatical } \\
\text { spelling, or } \\
\text { punctuation errors. }\end{array}$ & $\begin{array}{l}\text { Many grammatical, } \\
\text { spelling, or } \\
\text { punctuation errors. }\end{array}$ \\
\hline $\begin{array}{l}\text { Paragraph } \\
\text { Construction } \\
3 \text { points }\end{array}$ & $\begin{array}{l}\text { All paragraphs } \\
\text { include } \\
\text { introductory } \\
\text { sentence, } \\
\text { explanations or } \\
\text { details, and } \\
\text { concluding } \\
\text { sentence. } \\
\quad 3 \text { points }\end{array}$ & $\begin{array}{l}\text { Most paragraphs } \\
\text { include } \\
\text { introductory } \\
\text { sentence, } \\
\text { explanations or } \\
\text { details, and } \\
\text { concluding } \\
\text { sentence. } \\
\quad 2 \text { points }\end{array}$ & $\begin{array}{l}\text { Paragraphs } \\
\text { included related } \\
\text { information but } \\
\text { were typically not } \\
\text { constructed well. }\end{array}$ & $\begin{array}{l}\text { Paragraphing } \\
\text { structure was not } \\
\text { clear and sentences } \\
\text { were not typically } \\
\text { related within the } \\
\text { paragraphs. }\end{array}$ \\
\hline $\begin{array}{l}\text { Quality of } \\
\text { Information } \\
10 \text { points }\end{array}$ & $\begin{array}{l}\text { Information clearly } \\
\text { relates to the main } \\
\text { topic. It includes } \\
\text { several supporting } \\
\text { details and/or } \\
\text { examples. } \\
\qquad 10 \text { points }\end{array}$ & $\begin{array}{l}\text { Information clearly } \\
\text { relates to the main } \\
\text { topic. It provides 1- } \\
2 \text { supporting details } \\
\text { and/or examples. } \\
5 \text { points }\end{array}$ & $\begin{array}{l}\text { Information clearly } \\
\text { relates to the main } \\
\text { topic. No details } \\
\text { and/or examples } \\
\text { are given. } \\
\qquad 3 \text { points }\end{array}$ & $\begin{array}{l}\text { Information has } \\
\text { little or nothing to } \\
\text { do with the main } \\
\text { topic. }\end{array}$ \\
\hline $\begin{array}{l}\text { Sources } \\
2 \text { points }\end{array}$ & $\begin{array}{l}\text { All sources } \\
\text { (information and } \\
\text { graphics) are } \\
\text { accurately } \\
\text { documented in the } \\
\text { desired format. } \\
\qquad 2 \text { points }\end{array}$ & $\begin{array}{l}\text { All sources } \\
\text { (information and } \\
\text { graphics) are } \\
\text { accurately } \\
\text { documented, but a } \\
\text { few are not in the } \\
\text { desired format. } \\
\qquad 1.5 \text { points }\end{array}$ & $\begin{array}{l}\text { All sources } \\
\text { (information and } \\
\text { graphics) are } \\
\text { accurately } \\
\text { documented, but } \\
\text { many are not in the } \\
\text { desired format. } \\
\qquad 1 \text { point }\end{array}$ & $\begin{array}{l}\text { Some sources are } \\
\text { not accurately } \\
\text { documented. }\end{array}$ \\
\hline
\end{tabular}




\subsection{FINAL PAPER}

\begin{tabular}{|c|c|c|c|c|}
\hline CATEGORY & Excellent & Good & Fair & Poor \\
\hline $\begin{array}{l}\text { Organization } \\
5 \text { points }\end{array}$ & $\begin{array}{l}\text { Information is very } \\
\text { organized with } \\
\text { well-constructed } \\
\text { paragraphs and } \\
\text { subheadings. } \\
\qquad 5 \text { points }\end{array}$ & $\begin{array}{l}\text { Information is } \\
\text { organized with } \\
\text { well-constructed } \\
\text { paragraphs. } \\
\qquad 3 \text { points }\end{array}$ & $\begin{array}{l}\text { Information is } \\
\text { organized, but } \\
\text { paragraphs are not } \\
\text { well-constructed. } \\
\qquad 1 \text { point }\end{array}$ & $\begin{array}{l}\text { The information } \\
\text { appears to be } \\
\text { disorganized. }\end{array}$ \\
\hline $\begin{array}{l}\text { Mechanics } \\
5 \text { points }\end{array}$ & $\begin{array}{l}\text { No grammatical, } \\
\text { spelling or } \\
\text { punctuation errors. } \\
\qquad 5 \text { points }\end{array}$ & $\begin{array}{l}\text { Almost no } \\
\text { grammatical, } \\
\text { spelling or } \\
\text { punctuation errors } \\
\qquad 3 \text { points }\end{array}$ & $\begin{array}{l}\text { A few grammatical } \\
\text { spelling, or } \\
\text { punctuation errors. } \\
\qquad 1 \text { point }\end{array}$ & $\begin{array}{l}\text { Many grammatical, } \\
\text { spelling, or } \\
\text { punctuation errors. } \\
\qquad 0 \text { points }\end{array}$ \\
\hline $\begin{array}{l}\text { Paragraph } \\
\text { Construction } \\
5 \text { points }\end{array}$ & $\begin{array}{l}\text { All paragraphs } \\
\text { include } \\
\text { introductory } \\
\text { sentence, } \\
\text { explanations or } \\
\text { details, and } \\
\text { concluding } \\
\text { sentence. } \\
\qquad 5 \text { points }\end{array}$ & $\begin{array}{l}\text { Most paragraphs } \\
\text { include } \\
\text { introductory } \\
\text { sentence, } \\
\text { explanations or } \\
\text { details, and } \\
\text { concluding } \\
\text { sentence. } \\
\qquad 3 \text { points }\end{array}$ & $\begin{array}{l}\text { Paragraphs } \\
\text { included related } \\
\text { information but } \\
\text { were typically not } \\
\text { constructed well. }\end{array}$ & $\begin{array}{l}\text { Paragraphing } \\
\text { structure was not } \\
\text { clear and sentences } \\
\text { were not typically } \\
\text { related within the } \\
\text { paragraphs. }\end{array}$ \\
\hline $\begin{array}{l}\text { Quality of } \\
\text { Information } \\
25 \text { points }\end{array}$ & $\begin{array}{l}\text { Information clearly } \\
\text { relates to the main } \\
\text { topic. It includes } \\
\text { several supporting } \\
\text { details and/or } \\
\text { examples. } \\
\qquad 25 \text { points }\end{array}$ & $\begin{array}{l}\text { Information clearly } \\
\text { relates to the main } \\
\text { topic. It provides } 1 \text { - } \\
2 \text { supporting details } \\
\text { and/or examples. } \\
15 \text { points }\end{array}$ & $\begin{array}{l}\text { Information clearly } \\
\text { relates to the main } \\
\text { topic. No details } \\
\text { and/or examples } \\
\text { are given. } \\
\qquad 10 \text { points }\end{array}$ & $\begin{array}{l}\text { Information has } \\
\text { little or nothing to } \\
\text { do with the main } \\
\text { topic. }\end{array}$ \\
\hline 5 points & $\begin{array}{l}\text { All sources } \\
\text { (information and } \\
\text { graphics) are } \\
\text { accurately } \\
\text { documented in the } \\
\text { desired format. } \\
\qquad 5 \text { points }\end{array}$ & $\begin{array}{l}\text { All sources } \\
\text { (information and } \\
\text { graphics) are } \\
\text { accurately } \\
\text { documented, but a } \\
\text { few are not in the } \\
\text { desired format. } \\
\qquad 3 \text { points }\end{array}$ & $\begin{array}{l}\text { All sources } \\
\text { (information and } \\
\text { graphics) are } \\
\text { accurately } \\
\text { documented, but } \\
\text { many are not in the } \\
\text { desired format. } \\
\qquad 1 \text { point }\end{array}$ & $\begin{array}{l}\text { Some sources are } \\
\text { not accurately } \\
\text { documented. }\end{array}$ \\
\hline $\begin{array}{l}\text { Diagrams \& } \\
\text { Illustrations } \\
15 \text { points }\end{array}$ & $\begin{array}{l}\text { Diagrams and } \\
\text { illustrations are } \\
\text { neat, accurate and } \\
\text { add to the reader's } \\
\text { understanding of } \\
\text { the topic. } \\
\qquad 15 \text { points }\end{array}$ & $\begin{array}{l}\text { Diagrams and } \\
\text { illustrations are } \\
\text { accurate and add to } \\
\text { the reader's } \\
\text { understanding of } \\
\text { the topic. } \\
\qquad 10 \text { points }\end{array}$ & $\begin{array}{l}\text { Diagrams and } \\
\text { illustrations are } \\
\text { neat and accurate } \\
\text { and sometimes add } \\
\text { to the reader's } \\
\text { understanding of } \\
\text { the topic. } \\
\qquad 5 \text { points }\end{array}$ & $\begin{array}{l}\text { Diagrams and } \\
\text { illustrations are not } \\
\text { accurate OR do not } \\
\text { add to the reader's } \\
\text { understanding of } \\
\text { the topic. } \\
\qquad 0 \text { points }\end{array}$ \\
\hline
\end{tabular}




\subsection{FINAL PRESENTATION}

30 points possible

\begin{tabular}{|c|c|c|c|c|}
\hline CATEGORY & Excellent & Good & Fair & Poor \\
\hline $\begin{array}{l}\text { Timing/Length of } \\
\text { Presentation } \\
4 \text { points }\end{array}$ & $\begin{array}{l}\text { Within }+/-2 \\
\text { minutes of allotted } \\
\text { time. }\end{array}$ & $\begin{array}{l}\text { Within }+/-4 \\
\text { minutes of allotted } \\
\text { time. }\end{array}$ & $\begin{array}{l}\text { Within }+/-6 \\
\text { minutes of allotted } \\
\text { time. }\end{array}$ & $\begin{array}{l}\text { Exceeding allotted } \\
\text { time by } 7 \text { or more } \\
\text { minutes or less } \\
\text { than half of the } \\
\text { allotted time. } \\
\qquad 0 \text { points }\end{array}$ \\
\hline $\begin{array}{l}\text { Quality of } \\
\text { Presentation } \\
\text { Slides } \\
8 \text { points }\end{array}$ & $\begin{array}{l}\text { Presentation slides } \\
\text { are clear, attractive, } \\
\text { and support the } \\
\text { oral presentation. } \\
\text { Includes an } \\
\text { appropriate amount } \\
\text { of graphics and text } \\
\text { to engage the } \\
\text { audience. } \\
5 \text { points }\end{array}$ & $\begin{array}{l}\text { Presentation slides } \\
\text { are reasonably } \\
\text { clear and attractive } \\
\text { and support the } \\
\text { oral presentation. } \\
\text { Contains some } \\
\text { graphics and text to } \\
\text { engage the } \\
\text { audience. } \\
\qquad 3 \text { points }\end{array}$ & $\begin{array}{l}\text { Presentation slides } \\
\text { are somewhat } \\
\text { unclear, } \\
\text { unattractive, and } \\
\text { don't support the } \\
\text { oral presentation. } \\
\text { Lack of or excess } \\
\text { of text and graphics } \\
\text { fails to engage the } \\
\text { audience. } \\
\text { 1 point }\end{array}$ & $\begin{array}{l}\text { Presentation slides } \\
\text { are unclear, } \\
\text { unattractive, and } \\
\text { don't support the } \\
\text { oral presentation. } \\
\text { Lack of or excess } \\
\text { of text and graphics } \\
\text { fails to engage the } \\
\text { audience. } \\
\text { 0 points }\end{array}$ \\
\hline $\begin{array}{l}\text { Oral Presentation/ } \\
\text { Delivery } \\
8 \text { points }\end{array}$ & $\begin{array}{l}\text { Poised; clear; } \\
\text { articulate; } \\
\text { appropriate } \\
\text { volume; } \\
\text { enthusiasm; } \\
\text { confidence; } \\
\text { engages audience. } \\
\qquad 5 \text { points }\end{array}$ & $\begin{array}{l}\text { Clear on all points; } \\
\text { relatively good } \\
\text { articulation, } \\
\text { volume and } \\
\text { enthusiasm; } \\
\text { engages audience } \\
\text { during most of the } \\
\text { presentation. } \\
\qquad 3 \text { points }\end{array}$ & $\begin{array}{l}\text { Mumbling; } \\
\text { minimal eye } \\
\text { contact; very little } \\
\text { enthusiasm; } \\
\text { minimal audience } \\
\text { engagement. }\end{array}$ & $\begin{array}{l}\text { Inaudible; no } \\
\text { enthusiasm; } \\
\text { monotone; no } \\
\text { audience } \\
\text { engagement. }\end{array}$ \\
\hline $\begin{array}{l}\text { Quality of } \\
\text { Information } \\
10 \text { points }\end{array}$ & $\begin{array}{l}\text { Presentation } \\
\text { content is well- } \\
\text { researched and } \\
\text { thorough. Key } \\
\text { points support the } \\
\text { overall thesis. }\end{array}$ & $\begin{array}{l}\text { Presentation } \\
\text { content is mostly } \\
\text { accurate and } \\
\text { thorough. Key } \\
\text { points mostly } \\
\text { support the overall } \\
\text { thesis. }\end{array}$ & $\begin{array}{l}\text { Presentation } \\
\text { content contains } \\
\text { errors and reflects a } \\
\text { lack of thorough } \\
\text { research into the } \\
\text { topic. Key points } \\
\text { don't fully support } \\
\text { the thesis or are } \\
\text { lacking. } \\
\quad 3 \text { points }\end{array}$ & $\begin{array}{l}\text { Presentation } \\
\text { content is } \\
\text { erroneous and } \\
\text { reflects minimal } \\
\text { research into the } \\
\text { topic. Key points } \\
\text { either do not } \\
\text { support the thesis } \\
\text { or are lacking. } \\
\quad 0 \text { points }\end{array}$ \\
\hline
\end{tabular}




\subsection{REFERENCES}

Dewey, O. F. (2014). Transportation planning and development. Cambridge, Massachusetts: Harvard University. Retrieved from http://www.hks.harvard.edu/syllabus/SUP-652.pdf.

Dixon, K. (2008). Bicycle and pedestrian education program: Engineering curriculum module. Portland: Portland State University. Retrieved from https://www.pdx.edu/ibpi/sites/www.pdx.edu.ibpi/files/Curriculum\%20Report_0.pdf.

Sen, S., \& Umemoto, K. (2013). Syllabus book: A compilation of planning syllabi addressing issues of diversity and social justice. Association of Collegiate Schools of Planning: Committee on Diversity. Retrieved from http://www.acsp.org/sites/default/files/Syllabus\%20Book.pdf.

Florida Department of Transportation. (2014). Multimodal transportation best practices and model element. Retrieved from http://www.dot.state.fl.us/researchcenter/Completed_Proj/Summary_PL/FDOT-BDK85-977-49-rpt.pdf.

Weigand, L. (2010). Bicycle and pedestrian design curriculum expansion. Portland, Oregon: Oregon Transportation Research and Education Consortium. Retrieved from http://trec.pdx.edu/research/project/279/Bicycle_and_Pedestrian_Design_Curriculum_Ex pansion.

Williams, K., \& Seggerman, K. (2015). Mobility review guide. University of South Florida Center for Urban Transportation Research. Prepared for the Florida Department of Transportation. Retrieved from http://www.dot.state.fl.us/researchcenter/Completed_Proj/Summary_PL/FDOT-BDK84-977-02-rpt.pdf.

Courses with content not available online:

Academy for Teaching and Learning Excellence. (2015). Preparing for college teaching. Tampa, Florida: The University of South Florida.

Barber Torres, A. (2014). Sustainable transportation planning. Orlando, Florida: University of Central Florida.

Ewing, R. (n.d.). APA Sustainable Transportation Course. Utah: Department of City and Metropolitan Planning; University of Utah.

Williams, K. (2015). Multimodal transportation planning . Tampa, Florida: University of South Florida.

Tumlin, J. (2011, November). Planner's Training Service. Nelson Nygaard. 
APPENDIX A: COURSE SYLLABUS 


\section{Multimodal Transportation Planning Course Syllabus}

\section{Course Overview}

This course focuses on multimodal transportation planning, including planning for roadways, public transportation, bicycling, pedestrians, and the movement of freight. It addresses contemporary transportation planning from a multidisciplinary perspective, reviews the roles of various agencies and organizations in transportation planning, and emphasizes the relationship of transportation to land use and urban form. A goal of the course is to familiarize urban planning, engineering, and architecture/community design students with the diversity of contemporary transportation issues and best practices pertinent to these disciplines.

\section{Course Objectives}

At the completion of this course students will be able to:

1. Understand the historical evolution of transportation policy and practice in the U.S.;

2. Identify the social, economic and environmental implications of transportation alternatives, including the impact of transportation on urban form and public health;

3. Appreciate the institutional, political, legal and financial considerations in transportation planning;

4. Understand multimodal planning best practices in transportation and land use planning;

5. Evaluate the relative strengths and weaknesses of local transportation plans from a multimodal perspective.

\section{Texts and Materials}

Required Texts:

- Tumlin, J. (2012). Sustainable transportation planning: Tools for creating vibrant, healthy, and resilient communities. Hoboken, N.J.: John Wiley \& Sons, Inc.

- Lucas, K., Blumenberg, E., \& Weinberger, R. (Eds.). (2011). Auto motives: Understanding car use behaviors. Bingley, UK: Emerald Group Publishing.

o Note: This book may be digitally available through the school library - check with instructor for details.

- $\quad$ Rosenbloom, S. \& Beck, A. (2000). The practice of local government planning ( $3^{\text {rd }}$ ed.). Washington, D.C.: International City/County Management Association.

o Note: This book may be available through the school library - check with instructor for details.

Links to all other required readings are provided in the course syllabus. A complete list of readings is listed in alphabetical order at the end of this document.

Optional Texts:

- Hanson, S. \& Guiliano, G. (Eds.) (2004). The geography of urban transportation. New York: Guilford Press. 


\section{Course Assignments}

The course will be an interactive lecture/discussion format, with periodic assignments, and a final paper and presentation. In-class exercises will be conducted occasionally to allow students to actively practice what they are learning. Class participation is required and students will be queried about their readings and/or asked to discuss highlights of their readings in class. Students are encouraged to share with the class any transportation items of interest identified in the news, blogs, or on the web.

All assignments should be double-spaced and written in 12pt Times New Roman, with 1-inch margins. Sources should be referenced in APA format.

1. Reading Reflection \#1 - Due Week 4

Using knowledge gained from the required readings for Module 4, students will write a paper critiquing the conventional planning process as it relates to contemporary multimodal planning. Students may also use outside sources to further support their findings. The final product should be no longer than 4 pages. At least two references are required.

2. Reading Reflection \#2 - Due Week 7

Using knowledge gained from the required readings for Modules 5, 6, and 7, students will write a paper discussing influences on travel behavior. The paper should address two questions: 1) How does the built environment influence travel behavior?; and 2) What factors other than the built environment influence travel behavior and why? Students may also use outside sources to further support their findings. The final product should be no longer than 4 pages. At least three references are required.

3. Walkability Assessment - Due Week 8

Review the walkability checklist in the link provided below. Then choose a place to walk and use the checklist to document your findings. Summarize them in a brief report along with your ratings, any problem areas you identified, and provide some suggestions for improvement. Photographs are encouraged. Be prepared to discuss your findings in class. Students may collaborate during the assessment, but each must submit their own separate report. The final report should be between 8 and 10 pages.

Walkability Checklist:

http://www.pedbikeinfo.org/pdf/community_walkability_checklist.pdf

4. Transit Experience Report - Due Week 9

Students will ride the local bus to/from a destination and write a 2 to 4 page paper on the experience. Assessment of the experience can include timeliness of the bus, frequency of stops, total time of the trip, bus capacity, stations and support facilities, and overall comfort of the rider. Students should also include at least two photos from their experience.

5. Technique Report - Due Week 11

Students will select a transportation demand management technique of interest to them and submit a brief summary of the technique. Key aspects of the report include a description of the technique, how it works, and examples of where it has been applied. The report should be 
no longer than 4 pages and must include at least three references. Students shall choose a technique from the list below, although they are encouraged to suggest techniques or strategies not noted on the list. Students must communicate to the professor which technique they have chosen no later than Week 5.

Techniques:

- Traffic calming

- Road diets/rightsizing

- Bike share programs

- Car share programs

- Ridesharing

- Bus rapid transit

- Congestion pricing

- Transit oriented development

- Parking management/parking pricing

- Flexible work schedules/telework

- Access management

- Alternative funding (e.g. impact fees, tax increment financing, mobility fees)

- Other strategies upon approval from the instructor

6. Final Paper/Presentation

For the final project, students will be required to develop a case study or research paper on a critical transportation issue. Topics and findings will relate directly to the course material, but require independent research. The submission must reflect collegiate-level writing ability, include proper citations, and emulate the quality of an academic journal submission. To complete this assignment, students will need to employ critical thinking skills and be able to synthesize concepts and data.

This assignment will be completed in three stages:

a) Research Proposal. Students will submit a one-page proposal to the professor. The proposal shall include a thesis statement as well as a working outline of the final research paper. Students should include no fewer than 5 initial references.

b) Final Paper. The final paper should be between 7,000 and 10,000 words and include no fewer than 10 scholarly references. The paper is due on the last day of class, although students may submit a draft report for feedback prior to Week 14.

c) Final Presentation. Students shall present their findings during the last two weeks of class. Presentations must be conducted using PowerPoint or other similar presentation software and shall not exceed 20 minutes.

\section{Important Dates to Remember}

\begin{tabular}{|cc|}
\hline Item & Date \\
\hline Reading Reflection \#1 & Due Week 4 \\
\hline
\end{tabular}




\begin{tabular}{|cc|}
\hline Technique Topic & Due Week 5 \\
\hline Final Paper Research Proposal & Due Week 6 \\
\hline Reading Reflection \#2 & Due Week 7 \\
\hline Walkability Assessment & Due Week 8 \\
\hline Transit Experience Report & Due Week 9 \\
\hline Technique Report & Due Week 11 \\
\hline Final Paper & Due Week 15 \\
\hline Final Paper Presentation & Due Weeks 14-15 \\
\hline
\end{tabular}

\section{Grading}

\begin{tabular}{|cc|}
\hline \multicolumn{2}{|c|}{ Course Grading Structure } \\
\hline Assessment & Points \\
\hline Reading Reflection \#1 & $20(10 \%)$ \\
\hline Reading Reflection \#2 & $20(10 \%)$ \\
\hline Walkability Assessment & $20(10 \%)$ \\
\hline Transit Experience Report & $20(10 \%)$ \\
\hline Technique Report & $20(10 \%)$ \\
\hline Final Paper & $60(30 \%)$ \\
\hline Final Presentation & $30(15 \%)$ \\
\hline Attendance/Participation & $10(5 \%)$ \\
\hline \hline Total Points Possible & $\mathbf{2 0 0 ( 1 0 0 \% )}$ \\
\hline
\end{tabular}

\begin{tabular}{|cc|}
\hline \multicolumn{2}{|c|}{ Grading Scale } \\
\hline Grade & Qualifying Score \\
\hline A+ & $97-100$ \\
\hline A & $93-96$ \\
\hline A- & $90-92$ \\
\hline B + & $87-89$ \\
\hline B & $83-86$ \\
\hline B- & $80-82$ \\
\hline C+ & $77-79$ \\
\hline C & $73-76$ \\
\hline C- & $72-70$ \\
\hline D+ & $67-69$ \\
\hline D & $63-66$ \\
\hline D- & $60-62$ \\
\hline F & $0-59$ \\
\hline
\end{tabular}




\section{Schedule}

\begin{tabular}{|c|c|c|c|}
\hline Module & Lecture Topic & Readings & Assignments \\
\hline 1 & $\begin{array}{c}\text { Introduction and } \\
\text { Course } \\
\text { Overview } \\
\\
\text { Historical and } \\
\text { Emerging } \\
\text { Context for } \\
\text { Transportation } \\
\text { Planning and } \\
\text { Policy }\end{array}$ & $\begin{array}{l}\text { Required } \\
\text { Rosenbloom, S. \& Beck, A. (2000). The practice of } \\
\text { local government planning ( } 3^{\text {rd }} \text { ed.). Washington, D.C.: } \\
\text { International City/County Management Association. } \\
\text { o Chapter 9: Transportation Planning } \\
\text { - Federal Highway Administration \& Federal Transit } \\
\text { Administration. (2012). Federal strategies for } \\
\text { implementing requirements for LRTP update for the } \\
\text { Florida MPOs. Retrieved from } \\
\text { http://www.dot.state.fl.us/planning/revenueforecast/usdo } \\
\text { t.pdf. } \\
\text { Florida Department of Transportation. (2014). } \\
\text { Multimodal transportation best practices and model } \\
\text { element. Retrieved from } \\
\text { http://www.dot.state.fl.us/research- } \\
\text { center/Completed_Proj/Summary_PL/FDOT-BDK85- } \\
\text { 977-49-rpt.pdf. } \\
\text { o Chapter 3: Model Element for Small } \\
\text { U.S. Communities and Rural Areas } \\
\text { emphasis areas for federal fiscal year 2016. Retrieved } \\
\text { from } \\
\text { https://www.fhwa.dot.gov/planning/processes/metropoli } \\
\text { tan/mpo/fy_2016/fy2016pea.pdf. } \\
\text { U.S. Department of Transportation. (2015). Beyond } \\
\text { traffic 2045: Trends and choices. Retrieved from } \\
\text { https://www.transportation.gov/sites/dot.gov/files/docs/ } \\
\text { Draft_Beyond_Traffic_Framework.pdf. } \\
\text { Optional } \\
\text { Weiner, E. (1992). Urban transportation planning In the } \\
\text { United States: An historical overview. Westport, CT: } \\
\text { Praeger. Online access: } \\
\text { http://ntl.bts.gov/DOCS/UTP.html. }\end{array}$ & \\
\hline 2 & $\begin{array}{l}\text { Contemporary } \\
\text { Issues in } \\
\text { Transportation }\end{array}$ & $\begin{array}{l}\text { Required } \\
\text { - Transportation Research Board. (2013). Critical issues } \\
\text { in transportation. Retrieved from } \\
\text { http://onlinepubs.trb.org/Onlinepubs/general/criticalissu } \\
\text { es13.pdf. } \\
\text { - Gallivan, F., Rose, E., Ewing, R., Hamidi, S., \& Brown, } \\
\text { T. (2015). TCRP report 176: Quantifying transit's } \\
\text { impact on GHG emissions and energy use: The land use } \\
\text { component. Transportation Research Board of the } \\
\text { National Academies: Washington, D.C. Retrieved from } \\
\text { http://onlinepubs.trb.org/onlinepubs/tcrp/tcrp_rpt_176.p } \\
\text { df. }\end{array}$ & \\
\hline
\end{tabular}




\begin{tabular}{|c|c|c|c|}
\hline & & $\begin{array}{l}\text { o Executive Summary, Section 2, and Section } 4 . \\
\text { - Ewing, R., Bartholomew, K., Winkelman, S., Walters, } \\
\text { J., \& Chen, D. (2007). Growing cooler: The evidence on } \\
\text { urban development and climate change. Washington, } \\
\text { D.C.: Urban Land Institute. Retrieved from } \\
\text { http://www.smartgrowthamerica.org/documents/growin } \\
\text { gcoolerCH1.pdf. } \\
\text { o Chapter 1: Overview } \\
\text { - Tumlin, J. (2012). Sustainable transportation planning: } \\
\text { Tools for creating vibrant, healthy, and resilient } \\
\text { communities. Hoboken, NJ: John Wiley \& Sons. Inc. } \\
\text { o Chapter 3: Transportation and Public Health } \\
\text { American Society of Civil Engineers. (2013). 2013 } \\
\text { report card for America's infrastructure. Retrieved from } \\
\text { http://www.infrastructurereportcard.org/. } \\
\text { o Overview, Economic Impact, National Grades }\end{array}$ & \\
\hline 3 & $\begin{array}{l}\text { The Governance } \\
\text { and Equity of } \\
\text { Transportation }\end{array}$ & $\begin{array}{l}\text { Required } \\
\text { U.S. Department of Transportation. (2015). The } \\
\text { transportation planning process briefing book: Key } \\
\text { issues for transportation decisionmakers, officials, and } \\
\text { staff. Retrieved from } \\
\text { http://www.fhwa.dot.gov/planning/publications/briefing } \\
\text {-book/fhwahep15048.pdf. } \\
\text { Rall, J., Wheet, A., Farber, N. J., \& Reed, J. B. (2011). } \\
\text { Transportation governance and finance: A 50-state } \\
\text { review of state legislatures and departments of } \\
\text { transportation. National Conference of State } \\
\text { Legislatures. AASHTO Center for Excellence in Project } \\
\text { Finance. Retrieved from } \\
\text { http://www.ncsl.org/documents/transportation/FULL- } \\
\text { REPORT.pdf. } \\
\text { o Pages 39-163 “State Profiles” } \\
\text { Federal Highway Administration. (2011). } \\
\text { Environmental justice emerging trends and best } \\
\text { practices guidebook. Retrieved from } \\
\text { http://www.fhwa.dot.gov/environment/environmental_ju } \\
\text { stice/resources/guidebook/ejguidebook110111.pdf. } \\
\text { Executive Order 12898. (1994). Federal actions to } \\
\text { address environmental justice in minority populations } \\
\text { and low-income populations. Retrieved from } \\
\text { https://www.archives.gov/federal-register/executive- } \\
\text { orders/pdf/12898.pdf. } \\
\text { Executive Order 13166. (2000). Improving access to } \\
\text { services for persons with limited English proficiency. } \\
\text { Retrieved from http://www.gpo.gov/fdsys/pkg/FR-2000- } \\
\text { 08-16/pdf/00-20938.pdf. }\end{array}$ & \\
\hline 4 & Multimodal & Required & Assignment 1: \\
\hline
\end{tabular}




\begin{tabular}{|c|c|c|c|}
\hline & $\begin{array}{l}\text { Planning } \\
\text { Concepts and } \\
\text { Process }\end{array}$ & $\begin{array}{l}\text { Tumlin, J. (2012). Sustainable transportation planning: } \\
\text { Tools for creating vibrant, healthy, and resilient } \\
\text { communities. Hoboken, NJ: John Wiley \& Sons, Inc. } \\
\text { o Chapter 1: Introduction } \\
\text { o Chapter 2: Sustainable Transportation } \\
\text { - Litman, T. (2014). Introduction to multi-modal } \\
\text { transportation planning: Principles and practices. } \\
\text { Retrieved from } \\
\text { http://www.vtpi.org/multimodal_planning.pdf. } \\
\text { Boarnet, M.G. (2008). Transportation infrastructure and } \\
\text { sustainable development: New planning approaches for } \\
\text { urban growth. ACCESS, 33, 27-33. Retrieved from } \\
\text { http://www.uctc.net/access/33/Access\%2033\%20- } \\
\text { \%2005\%20-\%20New\%20Planning\%20Approaches.pdf. } \\
\text { Taylor, B. D. (2002). Rethinking traffic congestion. } \\
\text { ACCESS, 21, 8-16. Retrieved from } \\
\text { http://www.uctc.net/access/21/Access\%2021\%20- } \\
\text { \%2003\%20-\%20Rethinking\%20Congestion.pdf. } \\
\text { Optional } \\
\text { Hanson, S. \& Guiliano, G. (Eds.) (2004). The geography } \\
\text { of urban transportation. New York: Guilford Press. } \\
\text { o Chapter 5: The Urban Transportation Planning } \\
\text { Process } \\
\text { o Chapter 6: Reflections on the Planning Process } \\
\text { U.S. Department of Transportation. (2012). Best } \\
\text { planning practices: Metropolitan transportation plans. } \\
\text { Retrieved from } \\
\text { https://www.planning.dot.gov/documents/BestPlanningP } \\
\text { ractices_MTP.pdf. }\end{array}$ & $\begin{array}{c}\text { Reading } \\
\text { Reflection \#1 } \\
\text { Due }\end{array}$ \\
\hline 5 & $\begin{array}{l}\text { Transportation, } \\
\text { Land Use, and } \\
\text { Urban Form }\end{array}$ & $\begin{array}{l}\text { Required } \\
\text { Transportation Research Board. (2009). Special report } \\
\text { 298: Driving and the built environment: The effects of } \\
\text { compact development on motorized travel, energy use, } \\
\text { and CO } \text { emissions. Retrieved from }_{\text {http://onlinepubs.trb.org/Onlinepubs/sr/sr298.pdf. }} \\
\text { o Chapter 2: Trends in Development Patterns } \\
\text { o Chapter 3: Impacts of Land Use Patterns on } \\
\text { Vehicle Miles Traveled: Evidence from the } \\
\text { Literature } \\
\text { Shoup, D. C. (1999). The trouble with minimum parking } \\
\text { requirements. Transportation Research Part A: Policy } \\
\text { and Practice, 33(7), 549-574. Retrieved from } \\
\text { http://shoup.bol.ucla.edu/Trouble.pdf. } \\
\text { Seggerman, K. \& Williams, K. (2014). Managing the } \\
\text { impacts of bypasses on small and medium-sized } \\
\text { communities in Florida. Transportation Research } \\
\text { Record: Journal of the Transportation Research Board, } \\
\text { 2453, 46-53. Retrieved from }\end{array}$ & $\begin{array}{c}\text { Technique } \\
\text { Report Topic } \\
\text { Due }\end{array}$ \\
\hline
\end{tabular}




\begin{tabular}{|c|c|c|c|}
\hline & & $\begin{array}{l}\text { http://trrjournalonline.trb.org/doi/pdf/10.3141/2453-06. } \\
\text { Federal Highway Administration. (2011). FHWA } \\
\text { Scenario planning guidebook. Retrieved from } \\
\text { https://www.fhwa.dot.gov/planning/scenario_and_visual } \\
\text { ization/scenario_planning/scenario_planning_guidebook } \\
\text { /guidebook.pdf. } \\
\text { Optional } \\
\text { - Ewing, R. \& Cervero, R. (2010). Travel and the built } \\
\text { environment: A meta-analysis. Journal of the American } \\
\text { Planning Association, 76(3), 265-294. Retrieved from } \\
\text { http://reconnectingamerica.org/assets/Uploads/travelbuil } \\
\text { tenvironment20100511.pdf. }\end{array}$ & \\
\hline 6 & $\begin{array}{c}\text { Transportation } \\
\text { and Land Use } \\
\text { Planning Best } \\
\text { Practices }\end{array}$ & 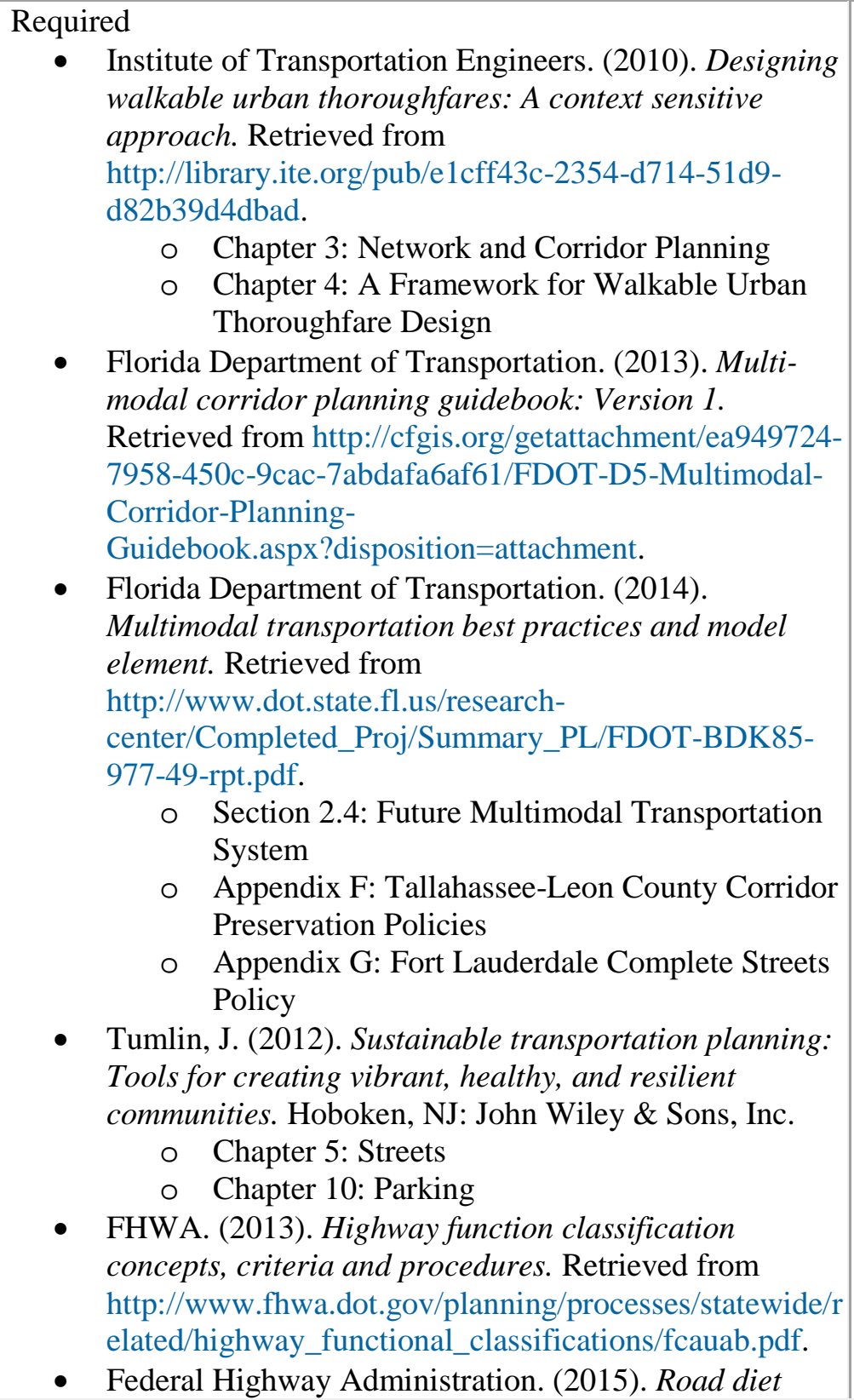 & $\begin{array}{l}\text { Final Paper } \\
\text { Research } \\
\text { Proposal Due }\end{array}$ \\
\hline
\end{tabular}




\begin{tabular}{|c|c|c|c|}
\hline & & $\begin{array}{l}\text { desk reference. Retrieved from } \\
\text { http://safety.fhwa.dot.gov/road_diets/desk_ref/sa_15_04 } \\
\text { 6.pdf. } \\
\text { - Federal Highway Administration. (2015). Proven safety } \\
\text { countermeasures: Roundabouts. Retrieved from } \\
\text { http://safety.fhwa.dot.gov/provencountermeasures/fhwa } \\
\text { _sa_12_005.pdf. } \\
\text { Optional } \\
\text { - City of Boston. (2013). Boston complete streets: Design } \\
\text { guidelines. Retrieved from } \\
\text { http://bostoncompletestreets.org/pdf/2013/BCS_Guideli } \\
\text { nes_LowRes.pdf. }\end{array}$ & \\
\hline 7 & $\begin{array}{c}\text { Travel Patterns } \\
\text { and Behavior }\end{array}$ & $\begin{array}{l}\text { Required } \\
\text { Crane, R. (1998). Travel by design? ACCESS, 12, 2-7. } \\
\text { Retrieved from } \\
\text { http://www.accessmagazine.org/articles/spring- } \\
\text { 1998/travel-design/. } \\
\text { - Levine, J. (1999). Access to choice. ACCESS, 14, 16-19. } \\
\text { Retrieved from } \\
\text { http://www.accessmagazine.org/articles/spring- } \\
\text { 1999/access-choice/. } \\
\text { Florida Department of Transportation. (2011). Florida } \\
\text { transportation trends and conditions: Travel demand. } \\
\text { Retrieved from } \\
\text { http://www.dot.state.fl.us/planning/trends/tc- } \\
\text { report/behavior.pdf. } \\
\text { Dill, J., Mohr, C., \& Ma, L. (2014). How can } \\
\text { psychological theory help cities increase walking and } \\
\text { bicycling? Journal of the American Planning } \\
\text { Association, 80(1), 36-51. Retrieved from } \\
\text { http://www.tandfonline.com/doi/pdf/10.1080/01944363. } \\
\text { 2014.934651. } \\
\text { Lucas, K., Blumenberg, E., \& Weinberger, R. (Eds.). } \\
\text { (2011). Auto motives: Understanding car use behaviors. } \\
\text { Bingley, UK: Emerald Group Publishing. } \\
\text { o Chapter 1: Understanding Auto Motives } \\
\text { o Chapter 2: Conceptualizing Car 'Dependence’ } \\
\text { o Chapter 5: Insights on Car-Use Behaviors from } \\
\text { Klinger, T., \& Lanzendorf, M. (2015). Moving between } \\
\text { mobility cultures: What affects the travel behavior of } \\
\text { new residents? Transportation, 1-29. Retrieved from } \\
\text { http://link.springer.com/article/10.1007\%2Fs11116-014- } \\
\text { 9574-x3. } \\
\text { Optional } \\
\text { - }\end{array}$ & $\begin{array}{l}\text { Assignment 2: } \\
\text { Reading } \\
\text { Reflection \#2 } \\
\text { Due }\end{array}$ \\
\hline 8 & $\begin{array}{c}\text { Non-Motorized } \\
\text { Transportation: } \\
\text { Walking and } \\
\text { Bicycling }\end{array}$ & $\begin{array}{l}\text { Required } \\
\text { • Tumlin, J. (2012). Sustainable transportation planning: } \\
\text { Tools for creating vibrant, healthy, and resilient } \\
\text { communities. Hoboken, NJ: John Wiley \& Sons, Inc. } \\
\text { o Chapter 6: Pedestrians }\end{array}$ & $\begin{array}{c}\text { Assignment 3: } \\
\text { Walkability } \\
\text { Assessment Due }\end{array}$ \\
\hline
\end{tabular}




\begin{tabular}{|c|c|c|c|}
\hline & & $\begin{array}{l}\text { o Chapter 7: Bicycles } \\
\text { - Initiative for Bicycle and Pedestrian Innovation. (2012). } \\
\text { Creating walkable + bikeable communities: A user } \\
\text { guide to developing pedestrian and bicycle master } \\
\text { plans. Retrieved from } \\
\text { http://www.pdx.edu/ibpi/sites/www.pdx.edu.ibpi/files/I } \\
\text { BPI\%20Master\%20Plan\%20Handbook\%20FINAL\%20( } \\
\text { 7.27.12).pdf. } \\
\text { o Chapter 1: Introduction } \\
\text { o Chapter 2: History and Evolution of Pedestrian } \\
\text { and Bicycle Master Planning } \\
\text { o Chapter 3: Preparing for the Planning Process } \\
\text { o Chapter 6: Establishing a Fact Base } \\
\text { o Chapter 7: Developing, Selecting, and } \\
\text { Prioritizing Plan Recommendations } \\
\text { Florida Department of Transportation. (2014). } \\
\text { Multimodal transportation best practices and model } \\
\text { element. Retrieved from } \\
\text { http://www.dot.state.fl.us/research- } \\
\text { center/Completed_Proj/Summary_PL/FDOT-BDK85- } \\
\text { 977-49-rpt.pdf. } \\
\text { o Chapter 2: Model Element for Urbanized Areas } \\
\text { (only read sections related to bicycles and } \\
\text { pedestrians) } \\
\text { Geller, R. (n.d.). Four types of cyclists. Retrieved from } \\
\text { https://www.portlandoregon.gov/transportation/44597?a } \\
\text { =237507. }\end{array}$ & \\
\hline 9 & $\begin{array}{l}\text { Transit and } \\
\text { Land Use }\end{array}$ & $\begin{array}{l}\text { Required } \\
\text { - Tumlin, J. (2012). Sustainable transportation planning: } \\
\text { Tools for creating vibrant, healthy, and resilient } \\
\text { communities. Hoboken, NJ: John Wiley \& Sons. Inc. } \\
\text { o Chapter 8: Transit } \\
\text { o Chapter 12: Stations and Station Areas } \\
\text { - City of Seattle. (2008). Seattle urban mobility plan } \\
\text { briefing book. Retrieved from } \\
\text { http://www.seattle.gov/transportation/briefingbook.htm. } \\
\text { o Chapter 9: Best Practices in Transit } \\
\text { City of San Diego. (1992). Transit-oriented } \\
\text { development design guidelines. Retrieved from } \\
\text { http://www.sandiego.gov/planning/documents/pdf/trans/ } \\
\text { todguide.pdf. } \\
\text { Florida Department of Transportation. (2011). A } \\
\text { framework for TOD in Florida. Retrieved from } \\
\text { http://www.reconnectingamerica.org/assets/Uploads/201 } \\
\text { 103FloridaTODFramework.pdf. } \\
\text { o Chapter 1: Introduction } \\
\text { o Chapter 2: Integrated Transit and Land Use } \\
\text { Planning } \\
\text { Florida Department of Transportation. (2014). } \\
\text { Multimodal transportation best practices and model }\end{array}$ & $\begin{array}{l}\text { Assignment 4: } \\
\text { Public } \\
\text { Transportation } \\
\text { Experience } \\
\text { Report Due }\end{array}$ \\
\hline
\end{tabular}




\begin{tabular}{|c|c|c|c|}
\hline & & $\begin{array}{l}\text { element. Retrieved from } \\
\text { http://www.dot.state.fl.us/research- } \\
\text { center/Completed_Proj/Summary_PL/FDOT-BDK85- } \\
\text { 977-49-rpt.pdf. } \\
\text { o Chapter } 2 \text { (sections relative to public } \\
\text { transportation) } \\
\text { Optional } \\
\text { - Florida Department of Transportation. (2012). Florida } \\
\text { TOD guidebook. Retrieved from } \\
\text { http://formbasedcodes.org/content/uploads/2014/03/flori } \\
\text { da-tod-guidebook.pdf. } \\
\text { Tomer, A., Kneebone, E., Puentes, R., \& Berube, A. } \\
\text { (2011). Missed opportunity: Transit and jobs in } \\
\text { metropolitan America. Brookings Institution. Retrieved } \\
\text { from } \\
\text { http://www.brookings.edu/ /media/research/files/reports } \\
\text { /2011/5/12-jobs-and-transit/0512_jobs_transit.pdf. }\end{array}$ & \\
\hline 10 & $\begin{array}{l}\text { Freight and } \\
\text { Goods } \\
\text { Movement }\end{array}$ & $\begin{array}{l}\text { Required } \\
\text { - Giuliano, G., O’Brien, T., Dablanc, L., \& Holliday, K. } \\
\text { (2013). NCFRP report 23: Synthesis of freight research } \\
\text { in urban transportation planning. Transportation } \\
\text { Research Board of the National Academies: } \\
\text { Washington, D.C. Retrieved from } \\
\text { http://onlinepubs.trb.org/onlinepubs/ncfrp/ncfrp_rpt_02 } \\
\text { 3.pdf } \\
\text { - Florida Department of Transportation. (2013). Florida } \\
\text { freight mobility and trade plan policy element: } \\
\text { Executive summary. Retrieved from } \\
\text { http://www.freightmovesflorida.com/docs/default- } \\
\text { source/fmtp-freight-information/freight-mobility-and- } \\
\text { trade-plan-policy-element-executive-summary_2013-06- } \\
\text { 19.pdf?sfvrsn=0. } \\
\text { City of Seattle. (2008). Seattle urban mobility plan } \\
\text { briefing book. Retrieved from } \\
\text { http://www.seattle.gov/transportation/briefingbook.htm. } \\
\text { o Chapter 10: Best Practices in Freight Movement } \\
\text { Federal Highway Administration. (2012). Freight and } \\
\text { land use handbook. Retrieved from } \\
\text { http://www.ops.fhwa.dot.gov/publications/fhwahop1200 } \\
\text { 6/fhwahop12006.pdf. } \\
\text { o Executive Summary } \\
\text { o Chapter 3: Freight Land Use and Sustainability } \\
\text { O Hanson, S. \& Guiliano, G. (Eds.) (2004). The geography } \\
\text { of urban transportation. New York: Guilford Press. } \\
\text { - Chapter 2: City Interactions: The Dynamics of } \\
\text { Passenger and Freight Flows }\end{array}$ & \\
\hline 11 & $\begin{array}{l}\text { Transportation } \\
\text { Demand and } \\
\text { Systems }\end{array}$ & $\begin{array}{l}\text { Required } \\
\text { - Tumlin, J. (2012). Sustainable transportation planning: } \\
\text { Tools for creating vibrant, healthy, and resilient }\end{array}$ & $\begin{array}{l}\text { Assignment 5: } \\
\text { Technique } \\
\text { Report Due }\end{array}$ \\
\hline
\end{tabular}




\begin{tabular}{|c|c|c|}
\hline & Management & $\begin{array}{l}\text { communities. Hoboken, NJ: John Wiley \& Sons. Inc. } \\
\text { o Chapter 11: Car Sharing } \\
\text { o Chapter 13: Transportation Demand } \\
\text { Management } \\
\text { - Federal Highway Administration. (2012). Creating an } \\
\text { effective program to advance transportation system } \\
\text { management and operations. Retrieved from } \\
\text { http://www.camsys.com/pubs/fhwahop12003.pdf. } \\
\text { Martin, E. \& Shaheen, S. (2011). The impacts of car } \\
\text { sharing on household vehicle ownership. ACCESS, 38, } \\
\text { 22-27. Retrieved from } \\
\text { http://www.accessmagazine.org/wp- } \\
\text { content/uploads/sites/7/2015/06/access38.pdf. } \\
\text { Shaheen, S. \& Guzman, S. (2011). Worldwide } \\
\text { bikesharing. ACCESS, 39, 22-27. Retrieved from } \\
\text { http://www.accessmagazine.org/wp- } \\
\text { content/uploads/sites/7/2015/06/access39.pdf. } \\
\text { City of Seattle. (2008). Seattle urban mobility plan } \\
\text { briefing book. Retrieved from } \\
\text { http://www.seattle.gov/transportation/briefingbook.htm. } \\
\text { o Chapter 7: Best Practices in Travel Demand } \\
\text { Management } \\
\text { - } \\
\text { Victoria Transport Policy Institute. (2014). Online } \\
\text { transportation demand management encyclopedia. } \\
\text { Retrieved from http://www.vtpi.org/tdm/ } \\
\text { Downs, A. (2005). Still stuck in traffic: Coping with } \\
\text { peak-hour traffic congestion. Washington, D.C.: } \\
\text { Brookings Institution Press. } \\
\text { o Chapter 6: Strategies for Reducing Congestion } \\
\text { and Four Basic Principles of Traffic } \\
\text { Chapter 7: Reducing Incident-Caused } \\
\text { Congestion }\end{array}$ \\
\hline 12 & $\begin{array}{c}\text { Funding } \\
\text { Multimodal } \\
\text { Transportation } \\
\text { Systems }\end{array}$ & $\begin{array}{l}\text { Required } \\
\text { - U.S. Department of Transportation. (2015). Beyond } \\
\text { traffic 2045: Trends and choices. Retrieved from } \\
\text { https://www.transportation.gov/sites/dot.gov/files/docs/ } \\
\text { Draft_Beyond_Traffic_Framework.pdf. } \\
\text { o "How We Align Decisions and Dollars”, } \\
\text { pp.148-187. } \\
\text { - Wachs, M. (2011). Transportation, jobs, and economic } \\
\text { growth. ACCESS, 38, 8-14. Retrieved from } \\
\text { http://www.uctc.net/access/38/access38_transportation_ } \\
\text { growth.pdf. } \\
\text { Sciara, G. \& Wachs, M. (2007). Metropolitan } \\
\text { transportation funding: Prospects, progress, and } \\
\text { practical considerations. Public Works Management \& } \\
\text { Policy, 12(1), 378-394. Retrieved from } \\
\text { http://pwm.sagepub.com/content/12/1/378.full.pdf+html } \\
\text { Shoup, D. (2004). The ideal source of public revenue. }\end{array}$ \\
\hline
\end{tabular}




\begin{tabular}{|c|c|c|}
\hline & & $\begin{array}{l}\text { Regional Science and Urban Economics, 34, 753-784. } \\
\text { Retrieved from } \\
\text { http://shoup.bol.ucla.edu/IdealSource.pdf. } \\
\text { Federal Highway Administration. (2012). Moving ahead } \\
\text { for progress in the 21st century act (MAP-21): A } \\
\text { summary of highway provisions. Retrieved from } \\
\text { https://www.fhwa.dot.gov/map21/docs/map21_summar } \\
\text { y_hgwy_provisions.pdf. } \\
\text { Federal Transit Administration. (2012). Moving ahead } \\
\text { for progress in the 21st century act (MAP-21): A } \\
\text { summary of public transportation provisions. Retrieved } \\
\text { from } \\
\text { http://www.fta.dot.gov/documents/MAP21_essay_style_- } \\
\text { summary_v5_MASTER.pdf. } \\
\text { Optional } \\
\text { Transportation Research Board. (2011). Special report } \\
\text { 303: Equity of evolving transportation finance } \\
\text { mechanisms. Transportation Research Board of the } \\
\text { National Academies: Washington, D.C. Retrieved from } \\
\text { http://onlinepubs.trb.org/onlinepubs/sr/sr303.pdf. } \\
\text { Galston, W.A. \& Davis, K. (2012). Setting priorities, } \\
\text { meeting needs: The case for a national infrastructure } \\
\text { bank. Governance Studies at Brookings Institution. } \\
\text { Retrieved from } \\
\text { http://www.brookings.edu/ /media/Research/Files/Paper } \\
\text { s/2012/12/13-infrastructure-galston- } \\
\text { davis/1213_infrastructure_galston_davis.pdf?la=en. }\end{array}$ \\
\hline 13 & $\begin{array}{c}\text { Evaluating } \\
\text { System } \\
\text { Performance }\end{array}$ & $\begin{array}{l}\text { Required } \\
\text { Tumlin, J. (2012). Sustainable transportation planning: } \\
\text { Tools for creating vibrant, healthy, and resilient } \\
\text { communities. Hoboken, NJ: John Wiley \& Sons. Inc. } \\
\text { o Chapter 14: Measuring Success } \\
\text { - McCahill, C. \& Ebeling, M. (2015). Tools for measuring } \\
\text { accessibility in an equity framework. Congress for the } \\
\text { New Urbanism } 23^{\text {rd }} \text { Annual Meeting. Retrieved from } \\
\text { https://www.cnu.org/sites/default/files/ssti_transpo_equi } \\
\text { ty.pdf } \\
\text { Initiative for Bicycle and Pedestrian Innovation. (2012). } \\
\text { Creating walkable + bikeable communities: A user } \\
\text { guide to developing pedestrian and bicycle master } \\
\text { plans. Retrieved from } \\
\text { http://www.pdx.edu/ibpi/sites/www.pdx.edu.ibpi/files/I } \\
\text { BPI\%20Master\%20Plan\%20Handbook\%20FINAL\%20( } \\
\text { 7.27.12).pdf. } \\
\text { o Chapter 9: Monitoring and Evaluating } \\
\text { U.S. Environmental Protection Agency. (2011). Guide } \\
\text { to sustainable transportation performance measures. } \\
\text { Retrieved from } \\
\text { http://www.epa.gov/sites/production/files/2014- }\end{array}$ \\
\hline
\end{tabular}




\begin{tabular}{|c|c|c|c|}
\hline & & $\begin{array}{l}\text { 01/documents/sustainable_transpo_performance.pdf. } \\
\text { Katz, P. (2013). The missing metric. Government } \\
\text { Finance Review, 29(4), 20-32. Retrieved from } \\
\text { http://www.gfoa.org/sites/default/files/GFR_AUG_13_2 } \\
\text { 0.pdf. } \\
\text { Optional } \\
\text { - Flyvbjerg, B., Skamris Holm, M. K., \& Buhl, S. L. } \\
\text { (2005). How (in) accurate are demand forecasts in } \\
\text { public works projects?: The case of transportation. } \\
\text { Journal of the American Planning Association, 71(2), } \\
\text { 131-146. Retrieved from } \\
\text { http://flyvbjerg.plan.aau.dk/Traffic91PRINTJAPA.pdf. }\end{array}$ & \\
\hline 14 & $\begin{array}{l}\text { Final Project } \\
\text { Presentations }\end{array}$ & N/A & $\begin{array}{c}\text { Final } \\
\text { Presentations: } \\
\text { Schedule TBA }\end{array}$ \\
\hline 15 & $\begin{array}{l}\text { Final Project } \\
\text { Presentations }\end{array}$ & N/A & $\begin{array}{c}\text { Final } \\
\text { Presentations: } \\
\text { Schedule TBA } \\
\text { Final Papers } \\
\text { Due }\end{array}$ \\
\hline
\end{tabular}

* Note: Class schedule is subject to revision. 


\section{Required Readings}

American Society of Civil Engineers. (2013). 2013 report card for America's infrastructure. Retrieved from http://www.infrastructurereportcard.org/.

Boarnet, M.G. (2008). Transportation infrastructure and sustainable development: New planning approaches for urban growth. ACCESS, 33, 27-33. Retrieved from http://www.uctc.net/access/33/Access\%2033\%20-\%2005\%20\%20New\%20Planning\%20Approaches.pdf.

City of San Diego. (1992). Transit-oriented development design guidelines. Retrieved from http://www.sandiego.gov/planning/documents/pdf/trans/todguide.pdf.

City of Seattle. (2008). Seattle urban mobility plan briefing book. Retrieved from http://www.seattle.gov/transportation/briefingbook.htm.

City of Seattle. (2008). Seattle urban mobility plan briefing book. Retrieved from http://www.seattle.gov/transportation/briefingbook.htm.

Crane, R. (1998). Travel by design? ACCESS, 12, 2-7. Retrieved from http://www.accessmagazine.org/articles/spring-1998/travel-design/.

Dill, J., Mohr, C., \& Ma, L. (2014). How can psychological theory help cities increase walking and bicycling? Journal of the American Planning Association, 80(1), 36-51. Retrieved from http://www.tandfonline.com/doi/pdf/10.1080/01944363.2014.934651.

Ewing, R., Bartholomew, K., Winkelman, S., Walters, J., \& Chen, D. (2007). Growing cooler: The evidence on urban development and climate change. Washington, D.C.: Urban Land Institute. Retrieved from http://www.smartgrowthamerica.org/documents/growingcoolerCH1.pdf.

Executive Order 12898. (1994). Federal actions to address environmental justice in minority populations and low-income populations. Retrieved from https://www.archives.gov/federal-register/executive-orders/pdf/12898.pdf.

Executive Order 13166. (2000). Improving access to services for persons with limited English proficiency. Retrieved from http://www.gpo.gov/fdsys/pkg/FR-2000-08-16/pdf/0020938.pdf

Federal Highway Administration \& Federal Transit Administration. (2012). Federal strategies for implementing requirements for LRTP update for the Florida MPOs. Retrieved from http://www.dot.state.fl.us/planning/revenueforecast/usdot.pdf.

Federal Highway Administration. (2011). Environmental justice emerging trends and best practices guidebook. Retrieved from http://www.fhwa.dot.gov/environment/environmental_justice/resources/guidebook/ejguid ebook110111.pdf.

Federal Highway Administration. (2011). FHWA Scenario planning guidebook. Retrieved from https://www.fhwa.dot.gov/planning/scenario_and_visualization/scenario_planning/scenar io_planning_guidebook/guidebook.pdf.

Federal Highway Administration. (2012). Creating an effective program to advance transportation system management and operations. Retrieved from http://www.camsys.com/pubs/fhwahop12003.pdf.

Federal Highway Administration. (2012). Freight and land use handbook. Retrieved from http://www.ops.fhwa.dot.gov/publications/fhwahop12006/fhwahop12006.pdf. 
Federal Highway Administration. (2012). Moving ahead for progress in the 21st century act (MAP-21): A summary of highway provisions. Retrieved from https://www.fhwa.dot.gov/map21/docs/map21_summary_hgwy_provisions.pdf.

Federal Highway Administration. (2013). Highway function classification concepts, criteria and procedures. Retrieved from http://www.fhwa.dot.gov/planning/processes/statewide/related/highway_functional_class ifications/fcauab.pdf.

Federal Highway Administration. (2015). Proven safety countermeasures: Roundabouts. Retrieved from http://safety.fhwa.dot.gov/provencountermeasures/fhwa_sa_12_005.pdf.

Federal Highway Administration. (2015). Road diet desk reference. Retrieved from http://safety.fhwa.dot.gov/road_diets/desk_ref/sa_15_046.pdf.

Federal Transit Administration. (2012). Moving ahead for progress in the 21st century act (MAP-21): A summary of public transportation provisions. Retrieved from http://www.fta.dot.gov/documents/MAP21_essay_style_summary_v5_MASTER.pdf

Florida Department of Transportation. (2011). A framework for TOD in Florida. Retrieved from http://www.reconnectingamerica.org/assets/Uploads/201103FloridaTODFramework.pdf.

Florida Department of Transportation. (2011). Florida transportation trends and conditions: Travel demand. Retrieved from http://www.dot.state.fl.us/planning/trends/tcreport/behavior.pdf.

Florida Department of Transportation. (2013). Florida freight mobility and trade plan policy element: Executive summary. Retrieved from http://www.freightmovesflorida.com/docs/default-source/fmtp-freightinformation/freight-mobility-and-trade-plan-policy-element-executive-summary_201306-19.pdf?sfvrsn $=0$.

Florida Department of Transportation. (2013). Multi-modal corridor planning guidebook: Version 1. Retrieved from http://cfgis.org/getattachment/ea949724-7958-450c-9cac7abdafa6af61/FDOT-D5-Multimodal-Corridor-PlanningGuidebook.aspx?disposition=attachment.

Florida Department of Transportation. (2014). Multimodal transportation best practices and model element. Retrieved from http://www.dot.state.fl.us/researchcenter/Completed_Proj/Summary_PL/FDOT-BDK85-977-49-rpt.pdf.

Gallivan, F., Rose, E., Ewing, R., Hamidi, S., \& Brown, T. (2015). TCRP report 176: Quantifying transit's impact on GHG emissions and energy use: The land use component. Transportation Research Board of the National Academies: Washington, D.C. Retrieved from http://onlinepubs.trb.org/onlinepubs/tcrp/tcrp_rpt_176.pdf.

Geller, R. (n.d.). Four types of cyclists. Retrieved from https://www.portlandoregon.gov/transportation/44597?a=237507

Giuliano, G., O’Brien, T., Dablanc, L., \& Holliday, K. (2013). NCFRP report 23: Synthesis of freight research in urban transportation planning. Transportation Research Board of the National Academies: Washington, D.C. Retrieved from http://onlinepubs.trb.org/onlinepubs/ncfrp/ncfrp_rpt_023.pdf

Initiative for Bicycle and Pedestrian Innovation. (2012). Creating walkable + bikeable communities: A user guide to developing pedestrian and bicycle master plans. Retrieved from

http://www.pdx.edu/ibpi/sites/www.pdx.edu.ibpi/files/IBPI\%20Master\%20Plan\%20Hand book\%20FINAL\%20(7.27.12).pdf. 
Institute of Transportation Engineers. (2010). Designing walkable urban thoroughfares: A context sensitive approach. Retrieved from http://library.ite.org/pub/e1cff43c-2354-d71451d9-d82b39d4dbad.

Katz, P. (2013). The missing metric. Government Finance Review, 29(4), 20-32. Retrieved from http://www.gfoa.org/sites/default/files/GFR_AUG_13_20.pdf.

Levine, J. (1999). Access to choice. ACCESS, 14, 16-19. Retrieved from http://www.accessmagazine.org/articles/spring-1999/access-choice/.

Litman, T. (2014). Introduction to multi-modal transportation planning: Principles and practices. Retrieved from http://www.vtpi.org/multimodal_planning.pdf.

Lucas, K., Blumenberg, E., \& Weinberger, R. (Eds.). (2011). Auto motives: Understanding car use behaviors. Bingley, UK: Emerald Group Publishing.

Martin, E. \& Shaheen, S. (2011). The impacts of car sharing on household vehicle ownership. ACCESS, 38, 22-27. Retrieved from http://www.accessmagazine.org/wpcontent/uploads/sites/7/2015/06/access38.pdf.

McCahill, C. \& Ebeling, M. (2015). Tools for measuring accessibility in an equity framework. Congress for the New Urbanism $23^{\text {rd }}$ Annual Meeting. Retrieved from https://www.cnu.org/sites/default/files/ssti_transpo_equity.pdf

Rall, J., Wheet, A., Farber, N. J., \& Reed, J. B. (2011). Transportation governance and finance: A 50-state review of state legislatures and departments of transportation. National Conference of State Legislatures. AASHTO Center for Excellence in Project Finance. Retrieved from http://www.ncsl.org/documents/transportation/FULL-REPORT.pdf.

Rosenbloom, S. \& Beck, A. (2000). The practice of local government planning ( $\left.3^{\text {rd }} \mathrm{ed}.\right)$. Washington, D.C.: International City/County Management Association.

Sciara, G. \& Wachs, M. (2007). Metropolitan transportation funding: Prospects, progress, and practical considerations. Public Works Management \& Policy, 12(1), 378-394. Retrieved from http://pwm.sagepub.com/content/12/1/378.full.pdf+html.

Seggerman, K. \& Williams, K. (2014). Managing the impacts of bypasses on small and mediumsized communities in Florida. Transportation Research Record: Journal of the Transportation Research Board, 2453, 46-53. Retrieved from http://trrjournalonline.trb.org/doi/pdf/10.3141/2453-06.

Shaheen, S. \& Guzman, S. (2011). Worldwide bikesharing. ACCESS, 39, 22-27. Retrieved from http://www.accessmagazine.org/wp-content/uploads/sites/7/2015/06/access39.pdf.

Shoup, D. (2004). The ideal source of public revenue. Regional Science and Urban Economics, 34, 753-784. Retrieved from http://shoup.bol.ucla.edu/IdealSource.pdf.

Shoup, D. C. (1999). The trouble with minimum parking requirements. Transportation Research Part A: Policy and Practice, 33(7), 549-574. Retrieved from http://shoup.bol.ucla.edu/Trouble.pdf.

Taylor, B. D. (2002). Rethinking traffic congestion. ACCESS, 21, 8-16. Retrieved from http://www.uctc.net/access/21/Access\%2021\%20-\%2003\%20-

\%20Rethinking\%20Congestion.pdf.

Transportation Research Board. (2009). Special report 298: Driving and the built environment: The effects of compact development on motorized travel, energy use, and $\mathrm{CO}_{2}$ emissions. Retrieved from http://onlinepubs.trb.org/Onlinepubs/sr/sr298.pdf.

Transportation Research Board. (2013). Critical issues in transportation. Retrieved from http://onlinepubs.trb.org/Onlinepubs/general/criticalissues13.pdf. 
Tumlin, J. (2012). Sustainable transportation planning: Tools for creating vibrant, healthy, and resilient communities. Hoboken, NJ: John Wiley \& Sons. Inc.

U.S. Department of Transportation. (2015). Beyond traffic 2045: Trends and choices. Retrieved from

https://www.transportation.gov/sites/dot.gov/files/docs/Draft_Beyond_Traffic_Framewor k.pdf.

U.S. Department of Transportation. (2015). Planning emphasis areas for federal fiscal year 2016. Retrieved from

https://www.fhwa.dot.gov/planning/processes/metropolitan/mpo/fy_2016/fy2016pea.pdf.

U.S. Department of Transportation. (2015). The transportation planning process briefing book:

Key issues for transportation decisionmakers, officials, and staff. Retrieved from

http://www.fhwa.dot.gov/planning/publications/briefing_book/fhwahep15048.pdf.

U.S. Environmental Protection Agency. (2011). Guide to sustainable transportation performance measures. Retrieved from http://www.epa.gov/sites/production/files/201401/documents/sustainable_transpo_performance.pdf.

Wachs, M. (2011). Transportation, jobs, and economic growth. ACCESS, 38, 8-14. Retrieved from http://www.uctc.net/access/38/access38_transportation_growth.pdf.

\section{Optional Readings}

City of Boston. (2013). Boston complete streets: Design guidelines. Retrieved from http://bostoncompletestreets.org/pdf/2013/BCS_Guidelines_LowRes.pdf.

Downs, A. (2005). Still stuck in traffic: Coping with peak-hour traffic congestion. Washington, D.C.: Brookings Institution Press.

Ewing, R. \& Cervero, R. (2010). Travel and the built environment: A meta-analysis. Journal of the American Planning Association, 76(3), 265-294. Retrieved from http://reconnectingamerica.org/assets/Uploads/travelbuiltenvironment20100511.pdf.

Florida Department of Transportation. (2012). Florida TOD guidebook. Retrieved from http://formbasedcodes.org/content/uploads/2014/03/florida-tod-guidebook.pdf.

Flyvbjerg, B., Skamris Holm, M. K., \& Buhl, S. L. (2005). How (in) accurate are demand forecasts in public works projects?: The case of transportation. Journal of the American Planning Association, 71(2), 131-146. Retrieved from http://flyvbjerg.plan.aau.dk/Traffic91PRINTJAPA.pdf.

Galston, W.A. \& Davis, K. (2012). Setting priorities, meeting needs: The case for a national infrastructure bank. Governance Studies at Brookings Institution. Retrieved from http://www.brookings.edu/ /media/Research/Files/Papers/2012/12/13-infrastructuregalston-davis/1213_infrastructure_galston_davis.pdf?la=en.

Hanson, S. \& Guiliano, G. (Eds.) (2004). The geography of urban transportation. New York: Guilford Press.

Klinger, T., \& Lanzendorf, M. (2015). Moving between mobility cultures: What affects the travel behavior of new residents? Transportation, 1-29. Retrieved from http://link.springer.com/article/10.1007\%2Fs11116-014-9574-x3.

Tomer, A., Kneebone, E., Puentes, R., \& Berube, A. (2011). Missed opportunity: Transit and jobs in metropolitan America. Brookings Institution. Retrieved from http://www.brookings.edu/ /media/research/files/reports/2011/5/12-jobs-andtransit/0512_jobs_transit.pdf. 
Transportation Research Board. (2011). Special report 303: Equity of evolving transportation finance mechanisms. Transportation Research Board of the National Academies: Washington, D.C. Retrieved from http://onlinepubs.trb.org/onlinepubs/sr/sr303.pdf.

U.S. Department of Transportation. (2012). Best planning practices: Metropolitan transportation plans. Retrieved from https://www.planning.dot.gov/documents/BestPlanningPractices_MTP.pdf.

Victoria Transport Policy Institute. (2014). Online transportation demand management encyclopedia. Retrieved from http://www.vtpi.org/tdm/

Weiner, E. (1992). Urban transportation planning In the United States: An historical overview. Westport, CT: Praeger. Online access: http://ntl.bts.gov/DOCS/UTP.html. 


\section{APPENDIX B: SAGA CITY EXERCISE}




\section{EXERCISE: Saga City}

The decisions that we make in land use and transportation planning have a lasting influence on growth patterns and quality of life for residents and visitors. The video, Saga City: Our

Communities Facing Climate Change, will illustrate how this occurs through the story of the City of Colvert.

1. View Part 1 of the video

2. List the transportation and land use actions that contribute to the problems experienced by the City of Colvert.

3. View Part 2 of the video.

4. List at least three strategies the City of Colvert used to achieve its vision of a better future. What additional strategies could the City have used to achieve their vision? 


\section{APPENDIX C: PUBLIC MEETING ROLE PLAY HANDOUT}




\section{Transportation Project \\ Public Meeting}

Objective: Have participants understand issues related to working with the public on transportation projects.

Directions: This is a role-playing exercise. Below is notice of a public meeting that you received in the mail. With this page is your role. Please read the public meeting notice, and then read the character sketch on the reverse side. Be prepared to act out your role. You may expand upon your character and his/her concerns, but try to keep within the facts you were given. The Public Information Specialist will tell you when it is time for the public meeting.

\section{Public Meeting Notice}

Wednesday, March 18, 2015

City Hall

Room 364

5:00 p.m.

The Department of Transportation is about to begin a project development study aimed at solving traffic problems on Hillsborough Avenue. Hillsborough Avenue currently operates at a level of service (LOS) F and is characterized by a high vehicular crash rate and several vehicularpedestrian incidents in the past year. The project will consider a variety of alternatives, including do nothing, adding new lanes, or a combination of solutions such as closing median openings, adding turn lanes at median openings, adding bike lanes, widening the sidewalks, and redesigning intersections to make them more pedestrian friendly. To learn more about the Hillsborough Avenue project, a public meeting has been scheduled for Thursday, March 18, 2015. 


\section{DOT Project Manager}

You are the project manager for the project and have worked at the Department of Transportation for ten years. Your public information specialist has scheduled a public meeting to obtain citizen input on your project. Your role is to explain the problem on Hillsborough Avenue and obtain comments or answer questions about the study. The DOT has not decided yet what it will do and is only beginning the study the problem. However, you secretly want to close as many median openings and driveways as possible to make the roadway safer. You also don't want any trees or special landscaping in the corridor, because it is expensive to maintain and can create sight distance problems. You suggest that the crashes on Hillsborough Avenue are related to the numerous median openings and driveways and try to sway public opinion in your favor. You have a tendency to get defensive when people question you, because you know what's best for the corridor.

Working with your public information specialist who will record citizen comments, you have about 15 minutes to get information from meeting attendees. Try to identify people who might support the median closures at the public meeting and what they might want in return. 


\section{Hispanic Woman}

You are a woman of Hispanic origin who lives in the neighborhood adjacent to the project. The meeting notice was in English, which you do not read well. You had to get someone to translate it for you. You are upset that the DOT didn't translate the notice into Spanish because there are a lot of Hispanic people in the neighborhood who don't read English very well. Many of them have children that cross Hillsborough Avenue every day to go to school. You are concerned about pedestrian safety and want to see something done to improve the school crossings.

The public information specialist will ask you to introduce yourself and to express any ideas or concerns you may have about the project. 


\section{Garden Club Representative}

You represent the local garden club, a politically active group that supported the successful candidate for mayor in a close election. The garden club is demanding more tree and shrub plantings along Hillsborough Avenue. The Mayor told you that the City would help maintain the landscaping, but that DOT may not allow it because it is a safety problem. Your friend in Ft. Lauderdale told you that DOT planted trees along the sidewalk and landscaped their median. You want to know whether or not DOT will help landscape the road and median in your neighborhood.

The public information specialist will ask you to introduce yourself and to express any ideas or concerns you may have about the project. 


\section{Bicycle Advocate}

Relations between bicyclists and the residents in the area are strained. Motorists complain about having to swerve into other lanes or wait in through lanes when making a left turn in order to avoid bicyclists. You are tired of residents trying to run you off the road with their cars, and as a bicycle advocate you feel that something needs to be done to improve your safety. You mainly want a bicycle lane on Hillsborough Avenue, but might support closing some of the driveways and median openings.

The public information specialist will ask you to introduce yourself and to express any ideas or concerns you may have about the project. 


\section{High School Principal}

You are a high school principal, who does not live in the area, but your school is near the project and many of your students cross Hillsborough Avenue. You are upset because no one notified you of the meeting. You were given a meeting notice by one of your teachers who found out from her neighborhood association president. There was a problem at the high school, so you arrive at the meeting late. You are upset that the meeting was not held in the community at a more convenient time. After all, the school has facilities that could be used for a public meeting. You burst into the room a few minutes after the meeting has started and demand to know why you weren't notified.

The public information specialist will ask you to introduce yourself and to express any ideas or concerns you may have about the project. 


\section{Asian Restaurant Owner}

You received a notice to attend the meeting, but it is difficult for you to go because you need to prepare for the evening dinner rush. You decide to go to the meeting anyway because you have a lot of competition in the area and have heard that the project is going to close your median opening. You feel that this will put you out of business because customers won't be able to access your business from the north side of Hillsborough Avenue anymore. You also feel that DOT has already made up its mind on the project and doesn't care what you have to say.

The public information specialist will ask you to introduce yourself and to express any ideas or concerns you may have about the project. 


\section{Neighborhood Association President}

You are president of a neighborhood association in the neighborhood adjacent to the project. You are fed up with through traffic in your neighborhood and also don't like bicyclists on Hillsborough Avenue because they think they own the road (and the road is for cars not bikes). You heard that the DOT is going to add bicycle lanes and widen the sidewalks, and you feel this will increase crime and make it dangerous to drive through your neighborhood on Hillsborough Avenue. You also feel that DOT has already made up its mind on the project and doesn't care what you have to say.

The public information specialist will ask you to introduce yourself and to express any ideas or concerns you may have about the project. 


\section{Transit User/Person of Limited Mobility}

You received notice of the public hearing and would like to attend. You have difficulty crossing Hillsborough Avenue because the signals are so far apart. You would like to see some safe midblock crossings. However, the meeting was not located near a transit stop and you are forced to ask a friend to drive you. This is not the first time that the transportation agency has done this. You have complained about this as an ADA issue, because it is difficult for you to walk long distances.

The public information specialist will ask you to introduce yourself and to express any ideas or concerns you may have about the project. 


\section{Shopping Center Developer}

You received notice of the public meeting, and are angry that the DOT is going to reconstruct Hillsborough Avenue. You were told by the DOT that there were no plans to change access on Hillsborough Avenue and that is why you invested a lot of money in redeveloping a site with a new shopping center. You feel you were betrayed and are intent on stopping the project. You have a lot of money and high priced lawyers ready to sue. You have brought your engineer to the meeting to dispute the need for the project.

The public information specialist will ask you to introduce yourself and to express any ideas or concerns you may have about the project. 


\section{Shopping Center Developer's Engineering Consultant}

You work for a major shopping center developer who is trying to stop an improvement project that has been proposed by DOT for Hillsborough Avenue and which may adversely impact your client's access. This is your biggest client and you want to get DOT to commit to preserving the existing full median opening that serves your client's shopping center. You will try to dispute the need to change this median opening.

The public information specialist may ask you to introduce yourself and to express any ideas or concerns you may have about the project. 


\section{Public Information Specialist}

You haven't had much training in public involvement and are not enthusiastic about working with the public. Your job is to start the meeting and tell people that the DOT project manager will present the project, after which they will have a chance to express their ideas or concerns.

When the DOT project manager is done, you open up the meeting for comments and ask each person to introduce themselves and to share their ideas or concerns. You were told to try to keep things moving along and to keep any one person from dominating the meeting. Generally, though, you are doing your best to keep people happy and are trying to smile and say "thank you" a lot. You will restate and record on the board any concerns that people raise so you can document the comments after the public meeting. You have never done this before, and occasionally you change the meaning a bit to fit what you think people are saying. 
APPENDIX D: EVALUATING SYSTEM PERFORMANCE HANDOUT 


\section{SUSTAINABLE TRANSPORTATION INDICATORS}

\begin{tabular}{|c|c|c|c|}
\hline Category & $\begin{array}{l}\text { Sustainability } \\
\text { Goals }\end{array}$ & Objectives & Performance Measures \\
\hline \multirow[t]{5}{*}{ Economic } & $\begin{array}{l}\text { Economic } \\
\text { productivity }\end{array}$ & $\begin{array}{l}\text { - Transport system } \\
\text { efficiency } \\
\text { - Transport system } \\
\text { integration } \\
\text { - Maximize accessibility } \\
\text { - Efficient pricing and } \\
\text { incentives }\end{array}$ & $\begin{array}{l}\text { - Per capita GDP } \\
\text { - Portion of budgets devoted to } \\
\text { transport } \\
\text { - Per capita congestion delay } \\
\text { - Efficient pricing (e.g. road, } \\
\text { parking, insurance, fuel, etc.) } \\
\text { - Efficient prioritization of } \\
\text { facilities }\end{array}$ \\
\hline & $\begin{array}{l}\text { Economic } \\
\text { development }\end{array}$ & $\begin{array}{l}\text { Economic and business } \\
\text { development }\end{array}$ & $\begin{array}{l}\text { - Access to education and } \\
\text { employment opportunities } \\
\text { - Support for local industries }\end{array}$ \\
\hline & $\begin{array}{l}\text { Energy } \\
\text { efficiency }\end{array}$ & $\begin{array}{l}\text { Minimize energy costs, } \\
\text { particularly petroleum } \\
\text { imports }\end{array}$ & $\begin{array}{l}\text { - Per capita transport energy } \\
\text { consumption } \\
\text { - Per capita use of imported fuels }\end{array}$ \\
\hline & Affordability & $\begin{array}{l}\text { - All residents can afford } \\
\text { access to basic (essential) } \\
\text { services and activities }\end{array}$ & $\begin{array}{l}\text { - Availability and quality of } \\
\text { affordable modes (walking, } \\
\text { cycling, ridesharing and public } \\
\text { transport) } \\
\text { - Portion of low-income } \\
\text { households that spend more } \\
\text { than } 20 \% \text { of budgets on } \\
\text { transport }\end{array}$ \\
\hline & $\begin{array}{l}\text { Efficient } \\
\text { transport } \\
\text { operations }\end{array}$ & $\begin{array}{l}\text { Efficient operations and } \\
\text { asset management } \\
\text { maximizes cost efficiency }\end{array}$ & $\begin{array}{l}\text { - Performance audit results } \\
\text { - Service delivery unit costs } \\
\text { compared with peers } \\
\text { - Service quality }\end{array}$ \\
\hline \multirow[t]{3}{*}{ Social } & Equity/fairness & $\begin{array}{l}\text { Transport system } \\
\text { accommodates all users, } \\
\text { including those with } \\
\text { disabilities, low incomes, } \\
\text { and other constraints }\end{array}$ & $\begin{array}{l}\text { - Transport system diversity } \\
\text { - Portion of destinations } \\
\text { accessible by people with } \\
\text { disabilities and low incomes }\end{array}$ \\
\hline & $\begin{array}{l}\text { Safety, security, } \\
\text { and health }\end{array}$ & $\begin{array}{l}\text { - Minimize risk of crashes } \\
\text { and assaults, and support } \\
\text { physical fitness }\end{array}$ & $\begin{array}{l}\text { - Per capita traffic casualty } \\
\text { (injury and death) rates } \\
\text { - Traveler assault (crime) rates } \\
\text { - Human exposure to harmful } \\
\text { pollutants } \\
\text { - Portion of travel by walking and } \\
\text { cycling }\end{array}$ \\
\hline & $\begin{array}{l}\text { Community } \\
\text { development }\end{array}$ & $\begin{array}{l}\text { - Help create inclusive and } \\
\text { attractive communities } \\
\text { - Support community } \\
\text { cohesion }\end{array}$ & $\begin{array}{l}\text { - Land use mix } \\
\text { - Walkability and bikeability } \\
\text { - Quality of road and street } \\
\text { environments }\end{array}$ \\
\hline
\end{tabular}




\begin{tabular}{|c|c|c|c|}
\hline & $\begin{array}{l}\text { Cultural } \\
\text { heritage } \\
\text { preservation }\end{array}$ & $\begin{array}{l}\text { - Respect and protect } \\
\text { cultural heritage } \\
\text { - Support cultural activities }\end{array}$ & $\begin{array}{l}\text { - Preservation of cultural } \\
\text { resources and traditions } \\
\text { - Responsiveness to traditional } \\
\text { communities }\end{array}$ \\
\hline \multirow[t]{5}{*}{ Environmental } & Climate stability & $\begin{array}{l}\text { - Reduce global warming } \\
\text { emissions } \\
\text { - Mitigate climate change } \\
\text { impacts }\end{array}$ & $\begin{array}{l}\text { - Per capita emissions of } \\
\text { greenhouse gases (CO2, CFCs, } \\
\text { CH4, etc) }\end{array}$ \\
\hline & $\begin{array}{l}\text { Prevent air } \\
\text { pollution }\end{array}$ & $\begin{array}{l}\text { - Reduce air pollution } \\
\text { emissions } \\
\text { - Reduce exposure to } \\
\text { harmful pollutants }\end{array}$ & $\begin{array}{l}\text { - Per capita emissions (PM, } \\
\text { VOCs, NOx, CO, etc) } \\
\text { - Air quality standards and } \\
\text { management plans }\end{array}$ \\
\hline & $\begin{array}{l}\text { Prevent noise } \\
\text { pollution }\end{array}$ & $\begin{array}{l}\text { - Minimize traffic noise } \\
\text { exposure }\end{array}$ & - Traffic noise levels \\
\hline & $\begin{array}{l}\text { Protect water } \\
\text { quality and } \\
\text { minimize } \\
\text { hydrological } \\
\text { damage }\end{array}$ & $\begin{array}{l}\text { - Minimize water pollution } \\
\text { - Minimize impervious } \\
\text { surface area }\end{array}$ & $\begin{array}{l}\text { - Per capita fuel consumption } \\
\text { - Management of used oil, leaks } \\
\text { and stormwater } \\
\text { - Per capita impervious surface } \\
\text { area }\end{array}$ \\
\hline & $\begin{array}{l}\text { Open space and } \\
\text { biodiversity } \\
\text { protection }\end{array}$ & $\begin{array}{l}\text { - Minimize transport } \\
\text { facility land use } \\
\text { - Encourage more compact } \\
\text { development } \\
\text { - Preserve high quality } \\
\text { habitat }\end{array}$ & $\begin{array}{l}\text { Per capita land devoted to } \\
\text { transport facilities } \\
\text { - Support for smart growth } \\
\text { development } \\
\text { - Policies to protect high value } \\
\text { farmlands and habitat }\end{array}$ \\
\hline $\begin{array}{l}\text { Good Governance } \\
\text { and Planning }\end{array}$ & $\begin{array}{l}\text { Integrated, } \\
\text { comprehensive, } \\
\text { and inclusive } \\
\text { planning }\end{array}$ & $\begin{array}{l}\text { - Clearly defined planning } \\
\text { process } \\
\text { - Integrated and } \\
\text { comprehensive analysis } \\
\text { - Strong citizen } \\
\text { engagement } \\
\text { - Least-cost planning (most } \\
\text { beneficial solutions are } \\
\text { selected and funded) }\end{array}$ & $\begin{array}{l}\text { - Clearly defined goals, } \\
\text { objectives and indicators } \\
\text { - Availability of planning } \\
\text { information and documents } \\
\text { - Portion of population engaged } \\
\text { in planning decisions } \\
\text { - Range of objectives, impacts } \\
\text { and options considered } \\
\text { - Transport funds can be spent } \\
\text { on alternative modes and } \\
\text { demand management if most } \\
\text { beneficial overall }\end{array}$ \\
\hline
\end{tabular}

Modified from Litman, T. (2015). Well measured: Developing indicators for sustainable and livable transport planning . Victoria Transport Policy Institute. Retrieved from http://www.vtpi.org/wellmeas.pdf. 


\begin{tabular}{|c|c|c|}
\hline & Example Strategies & $\begin{array}{l}\text { Indicators } \\
\text { /Measures }\end{array}$ \\
\hline \multirow{7}{*}{ 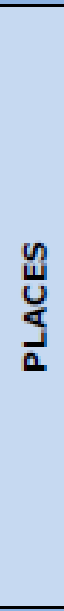 } & $\begin{array}{l}\text { Multimodal Districts - Encourage a mix of uses to make destinations closer } \\
\text { and within walking distance. }\end{array}$ & \multirow{7}{*}{$\begin{array}{l}\text { Population Density } \\
\text { Population-to- } \\
\text { Employment Ratio } \\
\text { Sidewalk Coverage } \\
\text { Jobs and Housing } \\
\text { Near Transit } \\
\text { Pedestrian Q/LOS } \\
\text { Bicycle Crashes, } \\
\text { Injuries \& Fatalities } \\
\text { Amount of Goods } \\
\text { Moved }\end{array}$} \\
\hline & $\begin{array}{l}\text { Multimodal Nodes - Encourage transit-ready densities and intensities of } \\
\text { development or redevelopment. }\end{array}$ & \\
\hline & Freight/Goods Districts - Preserve and strengthen connections to SIS & \\
\hline & $\begin{array}{l}\text { Freight/Goods Centers - Implement strateqies/projects in airport and } \\
\text { seaport master plans }\end{array}$ & \\
\hline & $\begin{array}{l}\text { Lower Intensity Residential Areas - Stabilize and protect established } \\
\text { neighborhoods. }\end{array}$ & \\
\hline & $\begin{array}{l}\text { Lower Intensity Commercial Areas - Optimize safe and easy access points } \\
\text { for all modes. }\end{array}$ & \\
\hline & $\begin{array}{l}\text { Lower Intensity Mixed Use Areas - Encourage horizontal and vertical } \\
\text { mixed use. }\end{array}$ & \\
\hline \multirow{6}{*}{ 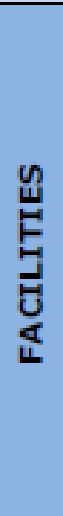 } & SIS Facilities - Implement managed lanes & \multirow{6}{*}{$\begin{array}{l}\text { Auto LOS } \\
\text { Travel Time } \\
\text { Reliability } \\
\text { Intersection Delay } \\
\text { Transit Q/LOS } \\
\text { Bicycle Q/LOS } \\
\text { Pedestrian Q/LOS } \\
\text { Crashes Involving } \\
\text { Pedestrians and } \\
\text { Bicyclists } \\
\text { Sidewalk Coverage }\end{array}$} \\
\hline & Primary Multimodal Facilities - Adopt multimodal Q/LOS standards. & \\
\hline & $\begin{array}{l}\text { Multimodal Facilities - Prioritize bicycle and pedestrian improvements to } \\
\text { facilities. }\end{array}$ & \\
\hline & Primary Commerce Facilities - Limit access to major intersections. & \\
\hline & $\begin{array}{l}\text { Commerce Facilities - Address potential safety conflicts between } \\
\text { pedestrians/bicyclists and autos/trucks. }\end{array}$ & \\
\hline & $\begin{array}{l}\text { Freight Connections - Prioritize and implement intersection improvements } \\
\text { to better accommodate trucks and enhance efficiency. }\end{array}$ & \\
\hline \multirow{7}{*}{$\underset{⿱ ㇒}{\frac{\sum}{n}}$} & $\begin{array}{l}\text { Develop a designated network of "Complete Streets" consistent with the } \\
\text { map of Multimodal Facilities to identify and prioritize specific } \\
\text { improvements. }\end{array}$ & \multirow{7}{*}{$\begin{array}{l}\text { Transit Mode Share } \\
\text { Bicycle Mode Share } \\
\text { Pedestrian Mode } \\
\text { Share } \\
\text { Average Commute } \\
\text { Trip Length } \\
\text { Countywide VMT } \\
\text { Per Capita } \\
\text { Truck Miles } \\
\text { Traveled } \\
\% \text { Miles Severely } \\
\text { Congested }\end{array}$} \\
\hline & Continue to strengthen congestion management processes and programs & \\
\hline & $\begin{array}{l}\text { Assess the effectiveness of existing transportation demand manaqement } \\
\text { (TDM) programs and refine the programs accordingly. }\end{array}$ & \\
\hline & $\begin{array}{l}\text { Create a common communication venue for local governments and } \\
\text { agencies to share information. }\end{array}$ & \\
\hline & dedicated funding coume for tranoit oner. & \\
\hline & 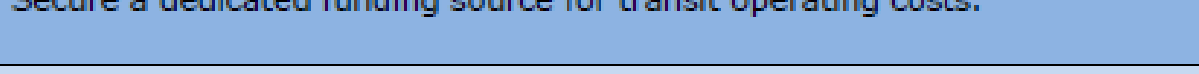 & \\
\hline & Periodically report on system status and trends. & \\
\hline \multicolumn{3}{|c|}{ Source: 1 -95 Corridor Mobility Plan (78) } \\
\hline
\end{tabular}

Florida Department of Transportation. (2014). Multimodal transportation best practices and model element. Retrieved from http://www.dot.state.fl.us/researchcenter/Completed_Proj/Summary_PL/FDOT-BDK85-977-49-rpt.pdf. 
Transportation Research and Education Center

Portland State University

1900 S.W. Fourth Ave., Suite 175

Portland, OR 97201 